\title{
IL-33 and Superantigenic Activation of Human Lung Mast Cells Induce the Release of Angiogenic and Lymphangiogenic Factors
}

\author{
Leonardo Cristinziano ${ }^{1,2}\left(\mathbb{D}\right.$, Remo Poto ${ }^{1,2}$, Gjada Criscuolo ${ }^{1,2,3}$, Anne Lise Ferrara ${ }^{1,2,4}(\mathbb{D}$, \\ Maria Rosaria Galdiero 1,2,3,4, Luca Modestino 1,2, Stefania Loffredo 1,2,3,4 (D), Amato de Paulis 1,2,3, \\ Gianni Marone ${ }^{1,2,3,4} \mathbb{D}$, Giuseppe Spadaro ${ }^{1,2,3}$ and Gilda Varricchi $1,2,3,4, * \mathbb{D}$
}

1 Department of Translational Medical Sciences, University of Naples Federico II, 80131 Naples, Italy; 1.cristinziano@gmail.com (L.C.); remo.poto@gmail.com (R.P.); gjada.criscuolo2@unina.it (G.C.); Anneliseferrara@gmail.com (A.L.F.); mrgaldiero@libero.it (M.R.G.); modestinoluca@gmail.com (L.M.); stefanialoffredo@hotmail.com (S.L.); depaulis@unina.it (A.d.P.); marone@unina.it (G.M.); spadaro@unina.it (G.S.)

2 World Allergy Organization (WAO) Center of Excellence, 80131 Naples, Italy

3 Center for Basic and Clinical Immunology Research (CISI), University of Naples Federico II, 80131 Naples, Italy

4 Institute of Experimental Endocrinology and Oncology (IEOS), National Research Council, 80131 Naples, Italy

* Correspondence: gildanet@gmail.com

\section{check for}

updates

Citation: Cristinziano, L.; Poto, R.; Criscuolo, G.; Ferrara, A.L.; Galdiero, M.R.; Modestino, L.; Loffredo, S.; de Paulis, A.; Marone, G.; Spadaro, G.; et al. IL-33 and Superantigenic

Activation of Human Lung Mast Cells Induce the Release of Angiogenic and Lymphangiogenic Factors. Cells 2021, 10, 145. https://doi.org/10.3390/ cells10010145

Received: 4 December 2020

Accepted: 9 January 2021

Published: 12 January 2021

Publisher's Note: MDPI stays neutral with regard to jurisdictional clai$\mathrm{ms}$ in published maps and institutional affiliations.

Copyright: $\odot 2021$ by the authors. Licensee MDPI, Basel, Switzerland. This article is an open access article distributed under the terms and conditions of the Creative Commons Attribution (CC BY) license (https:// creativecommons.org/licenses/by/ $4.0 /)$.

\begin{abstract}
Human lung mast cells (HLMCs) express the high-affinity receptor FceRI for IgE and are strategically located in different compartments of human lung, where they play a role in several inflammatory disorders and cancer. Immunoglobulin superantigens (e.g., protein A of Staphylococcus aureus and protein L of Peptostreptococcus magnus) bind to the variable regions of either the heavy $\left(\mathrm{V}_{\mathrm{H}^{3}}\right)$ or light chain $(\kappa)$ of IgE. IL-33 is a cytokine expressed by epithelial cells that exerts pleiotropic functions in the lung. The present study investigated whether immunoglobulin superantigens protein A and protein L and IL-33 caused the release of inflammatory (histamine), angiogenic (VEGF-A) and lymphangiogenic (VEGF-C) factors from HLMCs. The results show that protein A and protein $\mathrm{L}$ induced the rapid $(30 \mathrm{~min})$ release of preformed histamine from HLMCs. By contrast, IL-33 did not induce the release of histamine from lung mast cells. Prolonged incubation (12 h) of HLMCs with superantigens and IL-33 induced the release of VEGF-A and VEGF-C. Preincubation with IL-33 potentiated the superantigenic release of histamine, angiogenic and lymphangiogenic factors from HLMCs. Our results suggest that IL-33 might enhance the inflammatory, angiogenic and lymphangiogenic activities of lung mast cells in pulmonary disorders.
\end{abstract}

Keywords: allergy; asthma; histamine; IL-33; mast cell; protein A; protein L; superantigen; VEGF-A; VEGF-C

\section{Introduction}

Mast cells, localized in different compartments of human lung [1-4], are critical sentinels in immunity [5,6]. Mast cells were canonically considered primary effector cells of allergic disorders [2,7-9]. There is now evidence that these cells play a role in bacterial and viral infections [6,10-12], pulmonary disorders [13], angiogenesis [14-17], lymphangiogenesis [18,19], autoimmune diseases [20-22], and cancer [23-26].

Human lung mast cells express the high-affinity receptor (FceRI) for immunoglobulin $\mathrm{E}[1,27,28]$. IgE is a heterotetramer consisting of two identical heavy chains and two identical light chains that bind with high affinity $\left(\mathrm{Ka} \cong 10^{10} \mathrm{M}^{-1}\right)$ to FceRI on mast cells [29]. The human FceRI is a tetrameric complex comprising a single $\alpha$ chain, responsible for binding to IgE, two disulfide-linked $\gamma$ chains and a single $\beta$ chain [30,31]. Aggregation of IgE/FceRI complex by multivalent antigen, divalent anti-IgE or anti-FceRI initiates human mast cell activation [32,33] and the release of preformed (e.g., histamine), de novo synthesized lipid mediators [e.g., prostaglandin $\mathrm{D}_{2}\left(\mathrm{PGD}_{2}\right)$ and cysteinyl leukotriene $\mathrm{C}_{4}\left(\mathrm{LTC}_{4}\right)$ ], 
chemokines [34,35] and cytokines [8]. Human lung mast cells [14], like macrophages [36], basophils [37], and neutrophils [38], also release angiogenic (e.g., vascular endothelial growth factor A: VEGF-A) and lymphangiogenic factors (e.g., vascular endothelial growth factor C: VEGF-C) $[7,14,36]$.

Staphylococcus aureus (S. aureus) is a multifaceted human pathobiont which synthesizes several T [39] and B cell superantigens (SAgs) (e.g., protein A) [40]. Most clinical isolates of $S$. aureus synthesize and release protein A [41] which has two binding sites for human immunoglobulins (Igs): the classical site binds Fc $\gamma$ [42], whereas the alternative site binds the Fab portion of $15 \%$ to $50 \%$ of human polyclonal IgG, IgM, IgA, and IgE [43]. In particular, the alternative site of protein $A$ binds specifically to $V_{H^{3}}$, the largest of human Ig germline $\mathrm{V}_{\mathrm{H}}$ domain of human Igs [44]. Protein L, synthesized by Peptostreptococcus magnus (P. magnus) is another SAg that binds to the $\mathrm{V}$ domain of the $\mathrm{K}$ light chains of human Igs, including IgE [45-48]. In particular, protein L binds with high-affinity only human VkI, VkIII and VkIV subtypes, but does not interact with VkII subtype [49]. Several allergic [50-55] and autoimmune disorders [56,57], neoplasia [58-60], and immunodeficiencies [44] can be associated with SAgs.

Interleukin-33 (IL-33) is an IL-1 family member [61] expressed by lung epithelial and endothelial cells, and by other stromal cells [62-64]. IL-33, released after cellular stress or damage, acts as an alarmin that activates the immune response $[65,66]$. IL-33 binds to a heterodimer formed by its primary receptor ST2 and the co-receptor IL-1 receptor accessory protein (IL1RAP). Engagement of IL-33 receptor results in the release of mediators by different immune cells [67], including mast cells [17,22,68-74]. IL-33 is involved in allergic disorders [75-78], bacterial and viral infections [79-82] and cancer [66,83,84].

The aim of this study was to evaluate whether protein $\mathrm{A}$ and protein $\mathrm{L}$, alone or in combination with IL-33, induce the release of inflammatory, angiogenic and lymphangiogenic factors from primary human lung mast cells.

\section{Materials and Methods}

\subsection{Reagents}

Bovine serum albumin (BSA), PIPES [piperazine-N,N'-bis (2-ethanesulfonic acid)], L-glutamine, antibiotic-antimycotic solution (10,000 IU penicillin, $10 \mathrm{mg} / \mathrm{mL}$ streptomycin, and $25 \mu \mathrm{g} / \mathrm{mL}$ amphotericin B), IL-33 (R \& D Systems, Minneapolis, MN, USA), collagenase (Worthington Biochemical Co., Freehold, NJ, USA), fetal calf serum (FCS) (GIBCO, Grand Island, NY, USA), pronase (Calbiochem, La Jolla, CA, USA), RPMI 1640 with 25 mM HEPES buffer, Eagle's minimum essential medium (Flow Laboratories, Irvine, UK), Percoll (Pharmacia Fine Chemicals, Uppsala, Sweden), and CD117 MicroBead (Miltenyi Biotech, Bologna, Italy) were obtained commercially. The monoclonal antibody (mAb) anti-FceRI was a gift from Dr. Lawrence M. Lichtenstein (The Johns Hopkins University, Baltimore, MD, USA). Human IgG anti-IgE (H-aIgE) was purified from the serum of a patient with atopic dermatitis as previously described $[85,86]$. The specificity and activity of $\operatorname{Ig} G$ anti-IgE were described elsewhere [85].

\subsection{Human Monoclonal IgM and IgE and Human Polyclonal IgG}

Monoclonal IgM, purified from the serum of patients with Waldenström's macroglobulinemia, were described previously [87]. Variable regions of these monoclonal IgM were determined using a panel of primary sequence-dependent $V_{H}$ family specific reagents that identify framework regions [88]. Human polyclonal IgG were purified from the serum of healthy donors [89]. Monoclonal $\operatorname{IgE} \lambda$ and $\kappa$, purified from the serum of patients with $\operatorname{IgE}$ myeloma, were described elsewhere $[89,90]$.

\subsection{Isolation of $H L M C S$}

The study was approved by the Ethics Committee of the University of Naples Federico II (Protocol: Human MC No. 7/19). The lung tissue was obtained from patients who were seronegative for HIV-1, HCV, and HBV undergoing thoracic surgery. HLMCs were 
isolated from human lung tissue by a modification of the method previously described [14]. The enzymatic dispersion tissue yields $\approx 5 \times 10^{5}$ mast cells per gram of lung tissue. The purity of these populations ranged from $3 \%$ to $18 \%$. HLMCs were partially purified by flotation through a discontinuous Percoll gradient [87]. Mast cell purity using this technique ranged from $49 \%$ to $81 \%$ and was assessed by alcian blue staining.

\subsection{Histamine Release}

HLMCs $\left(\approx 3 \times 10^{4}\right.$ mast cells per tube) were resuspended in PIPES buffer containing, in addition to PIPES $(25 \mathrm{mM}), \mathrm{CaCl}_{2}(2 \mathrm{mM})$ and dextrose $(1 \mathrm{~g} / \mathrm{L}) .0 .3 \mathrm{~mL}$ of the cell suspensions were placed in $12 \times 75 \mathrm{~mm}$ polyethylene tubes. $0.2 \mathrm{~mL}$ of each prewarmed releasing stimulus was added, and incubation was continued at $37^{\circ} \mathrm{C}$ for $45 \mathrm{~min}$ [91]. At the end of incubation, cells were centrifuged $\left(1000 \times g, 4^{\circ} \mathrm{C}, 5 \mathrm{~min}\right)$ and supernatants were stored at $-20{ }^{\circ} \mathrm{C}$ for subsequent assay of histamine. Histamine was measured in duplicate determinations with an automated fluorometric technique [92].

\subsection{VEGF-A and VEGF-C Release}

HLMCs $\left(\approx 8 \times 10^{4}\right.$ mast cells / per tube) were incubated $\left(37^{\circ} \mathrm{C}, 12 \mathrm{~h}\right)$ in RPMI 1640 containing 5\% FCS, 2 mM L-glutamine, and 1\% antibiotic-antimycotic solution, and activated with various concentrations of protein $\mathrm{A}$ or protein $\mathrm{L}$, alone or in combination with IL-33. At the end of incubation, cells were centrifuged $\left(1000 \times g, 4{ }^{\circ} \mathrm{C}, 5 \mathrm{~min}\right)$ and the supernatants were stored at $-80^{\circ} \mathrm{C}$ for subsequent assay of mediator release. VEGF-A and VEGF-C were measured in duplicate determinations using ELISA kits (R\&D System, Minneapolis, MN, USA [93]. The ELISA sensitivity is 31-2000 pg/mL for VEGF-A and $62-4000 \mathrm{pg} / \mathrm{mL}$ for VEGF-C.

\subsection{Statistical Analysis}

Data were analyzed with the GraphPad Prim 6 software package (GraphPad Software, La Jolla, CA, USA). Values were expressed as mean \pm SEM (standard error of the mean). Statistical analysis was performed using Student's $t$-test or one-way analysis of variance [71]. Correlations between two variables were assessed by Spearman's rank correlation analysis and reported as coefficients of correlation (r). A $p$ value $\leq 0.05$ was considered statistically significant.

\section{Results}

\subsection{Effects of Human IgG Anti-IgE on the Release of Angiogenic and Lymphangiogenic Factors from HLMCS}

We have previously reported that IgG anti-IgE purified from the serum of a small percentage of atopic dermatitis patients induced histamine release from human basophils [85] and lung mast cells [94]. The activating effects of human IgG anti-IgE (H-aIgE) were mediated by the interaction with membrane-bound $\operatorname{IgE}$ on human basophils and mast cells. In a series of experiments, we used this human autoantibody to activate HLMCs in vitro. $\mathrm{H}$-aIgE $\left(10^{-2}\right.$ to $\left.3 \mu \mathrm{g} / \mathrm{mL}\right)$ caused a concentration-dependent release of both angiogenic (VEGF-A) and lymphangiogenic factors (VEGF-C) from four different preparations for HLMCs (Figure 1A). As a control, we found that the same concentrations of H-aIgE induced a concentration-dependent release of histamine. Similar results were obtained when HLMCs were activated by increasing concentrations $\left(10^{-1}\right.$ to $\left.3 \mu \mathrm{g} / \mathrm{mL}\right)$ of monoclonal antibody (mAb) anti-FceRI (Table 1). Three preparations of human polyclonal IgG $\left(10^{-2}\right.$ to $3 \mu \mathrm{g} / \mathrm{mL}$ ) did not cause the release of histamine, VEGF-A, and VEGF-C (Table 2). These results indicate that mast cells isolated from human lung parenchyma express IgE bound to FceRI. Figure 1B shows that there was a significant correlation between the production of VEGF-A and histamine release caused by H-aIgE $(r=0.76 ; p<0.001)$. Similarly, there was a significant correlation between the production of VEGF-C and histamine release $(\mathrm{r}=0.57 ; p<0.05)$ (Figure 1C) and between the production of angiogenic (VEGF-A) and lymphangiogenic (VEGF-C) factors $(\mathrm{r}=0.89 ; p<0.001)$ (Figure 1D). 

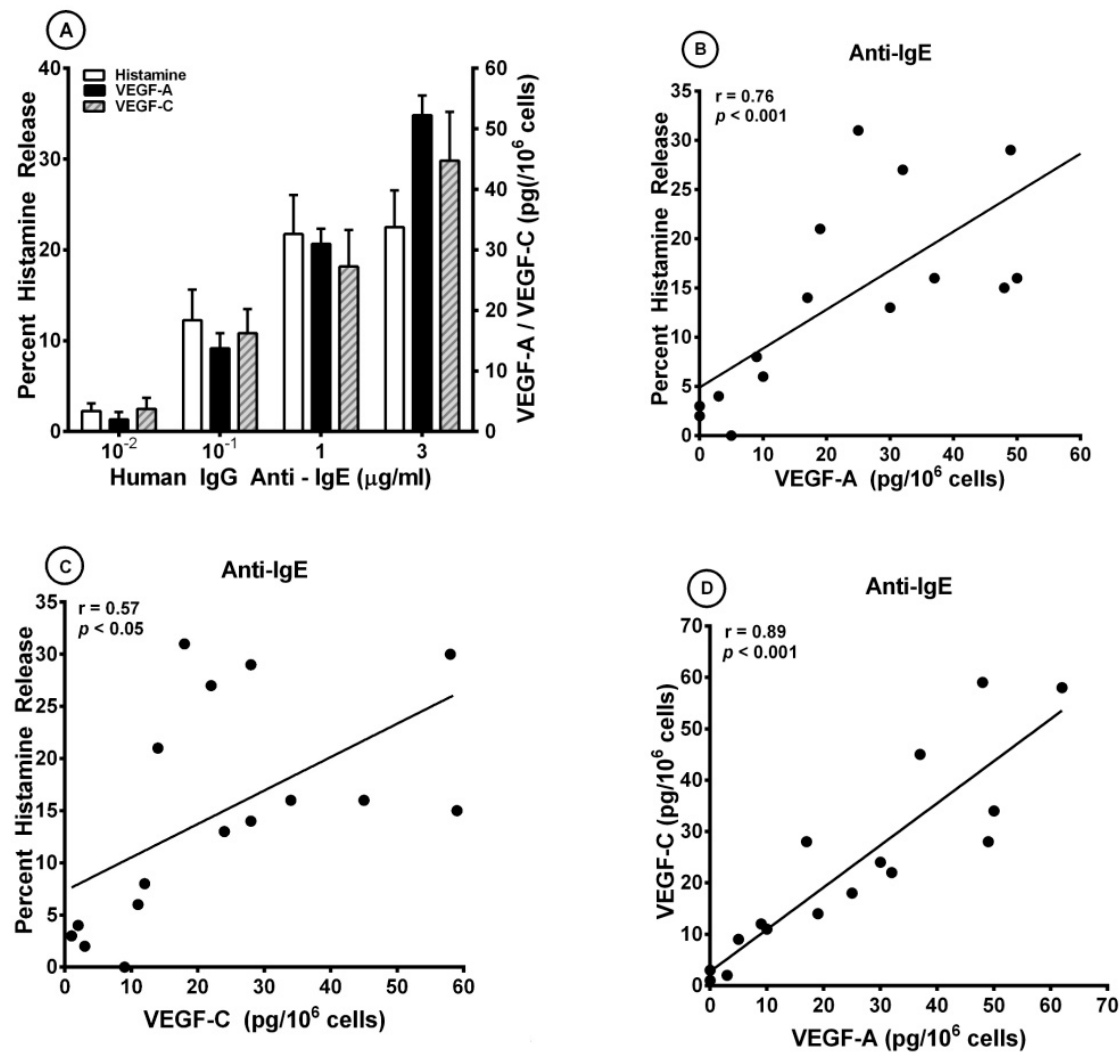

Figure 1. (A) Effects of increasing concentrations of human IgG anti-IgE purified from the serum of an atopic dermatitis patient $[85,95]$ on histamine release and the production of VEGF-A and VEGF-C from four different preparations of human lung mast cells (HLMCs). HLMCs were incubated (45 min at $37^{\circ} \mathrm{C}$ ) with the indicated concentrations of IgG anti-IgE for histamine secretion or $\left(12 \mathrm{~h}\right.$ at $\left.37^{\circ} \mathrm{C}\right)$ for VEGF-A and VEGF-C release. Each bar is the mean \pm SEM; $(\mathbf{B})$ Correlation $(\mathrm{r}=0.76 ; p<0.001)$ between VEGF-A release and the percent histamine secretion caused by human IgG anti-IgE from HLMCs; (C) Correlation ( $r=0.57 ; p<0.05)$ between VEGF-C release and the percent histamine secretion caused by human IgG anti-IgE from HLMCs; (D) Correlation ( $\mathrm{r}=0.89 ; p<0.001)$ between VEGF-A and VEGF-C release caused by human IgG anti-IgE from HLMCs.

Table 1. Effects of increasing concentrations of monoclonal antibody anti-FceRI on histamine release and the production of VEGF-A (angiogenic) and VEGF-C (lymphangiogenic) from human lung mast cells.

\begin{tabular}{|c|c|c|c|}
\hline \multicolumn{4}{|c|}{ Monoclonal Antibody (mAb) Anti-FceRI ( $\mu \mathrm{g} / \mathrm{mL})$} \\
\hline & $10^{-1}$ & 1 & 3 \\
\hline $\begin{array}{c}\text { Percent } \\
\text { Histamine } \\
\text { Release }\end{array}$ & $14.0 \pm 3.21$ & $23.33 \pm 4.80$ & $24.66 \pm 3.84$ \\
\hline $\begin{array}{c}\text { VEGF-A } \\
\text { (pg/10 } 10^{6} \text { cells) }\end{array}$ & $16.33 \pm 3.28$ & $28.66 \pm 1.45$ & $51.33 \pm 3.84$ \\
\hline $\begin{array}{c}\text { VEGF-C } \\
\text { (pg/10 } 6 \text { cells) }\end{array}$ & $16.33 \pm 4.91$ & $29.33 \pm 6.43$ & $45.0 \pm 8.14$ \\
\hline
\end{tabular}

Human lung mast cells purified from three different donors were incubated with the indicated concentrations of $\mathrm{mAb}$ anti-FceRI to evaluate histamine secretion $\left(45 \mathrm{~min}\right.$ at $\left.37^{\circ} \mathrm{C}\right)$ or VEGF-A and VEGF-C release $\left(12 \mathrm{~h}\right.$ at $\left.37^{\circ} \mathrm{C}\right)$. Each value is the mean $\pm \mathrm{SEM}$. 
Table 2. Effect of human polyclonal IgG on histamine release and the production of VEGF-A and VEGF-C from human lung mast cells.

\begin{tabular}{ccccc}
\hline \multicolumn{5}{c}{ Human Polyclonal IgG $(\boldsymbol{\mu g} / \mathrm{mL})$} \\
\hline $\begin{array}{c}\text { Percent } \\
\text { Histamine } \\
\text { Release }\end{array}$ & $1.66 \pm 1.20$ & $1.66 \pm 0.88$ & $1.33 \pm 0.88$ & $\mathbf{1}$ \\
\hline $\begin{array}{c}\text { VEGF-A } \\
\text { (pg/106 cells) }\end{array}$ & $0.33 \pm 0.33$ & $2.30 \pm 0.33$ & $1.66 \pm 1.20$ & $0.66 \pm 0.66$ \\
\hline $\begin{array}{c}\text { VEGF-C } \\
\left(\mathbf{p g} / \mathbf{1 0}^{\mathbf{6}} \text { cells }\right)\end{array}$ & $1.16 \pm 0.60$ & $0.50 \pm 0.50$ & $1.4 \pm 0.94$ & $0.83 \pm 0.44$ \\
\hline
\end{tabular}

Increasing concentrations of human polyclonal IgG purified from the serum of three healthy donors as described elsewhere [89] were incubated with three different preparations of human lung mast cells (HLMCs). HLMCs were incubated $\left(45 \mathrm{~min}\right.$ at $\left.37^{\circ} \mathrm{C}\right)$ with the indicated concentrations of IgG to evaluate histamine secretion or VEGF-A and VEGF-C release $\left(12 \mathrm{~h}\right.$ at $\left.37^{\circ} \mathrm{C}\right)$. Each value is the mean $\pm \mathrm{SEM}$.

\subsection{Effect of Superantigenic Protein A on the Release of Angiogenic and Lymphangiogenic Factors} from HLMCS

S. aureus colonization is associated with bronchial asthma [52,95]. S. aureus superantigens trigger airway inflammation and increased airway responsiveness, and facilitate allergic sensitization in asthma models [96]. It has been shown that S. aureus and protein A can activate human mast cells through different mechanisms $[47,97]$. More recently, we have demonstrated that protein $\mathrm{A}$ induced the release of lipid mediators from human cardiac mast cells through the engagement of $\operatorname{IgE~} \mathrm{V}_{\mathrm{H}} 3^{+}$bound to FcERI [98]. Figure 2A shows that protein A (30 to $600 \mathrm{nM}$ ) caused a concentration-dependent release of both VEGF-A and VEGF-C from different preparations of HLMCs. The same concentrations of protein A caused a dose-dependent release of histamine. Protein A contains five homologous repeated domains, each of which binds to human Igs, including IgE [42,43]. Preincubation $\left(15 \mathrm{~min}, 37^{\circ} \mathrm{C}\right)$ of protein $\mathrm{A}(300 \mathrm{nM})$ with $\operatorname{IgM~V} \mathrm{V}_{\mathrm{H}} 3^{+}(10 \mu \mathrm{g} / \mathrm{mL})$, but not $\operatorname{IgM~V} \mathrm{V}_{\mathrm{H}} 6^{+}$ $(10 \mu \mathrm{g} / \mathrm{mL})$, blocked the histamine-releasing activity of protein $\mathrm{A}$ (Table 3$)$. These results suggest that the immunoglobulin superantigen protein A activates HLMCs through the binding to $\operatorname{IgE~} \mathrm{V}_{\mathrm{H}} 3^{+}$bound to FceRI.

Table 3. Effects of preincubation of protein A with human monoclonal $\operatorname{Ig} M V_{\mathrm{H}} 3^{+}$or $\operatorname{IgM~V} \mathrm{V}_{\mathrm{H}} 6^{+}$on the activation of HLMCs.

\begin{tabular}{|c|c|}
\hline Stimulus & Percent Histamine Release \\
\hline Protein A & $18.3 \pm 0.9$ \\
\hline $\operatorname{IgM~V} \mathrm{H} 3^{+}$ & $0.3 \pm 0.3$ \\
\hline $\operatorname{IgM~V} \mathrm{H} 3^{+}+$Protein $\mathrm{A}$ & $3.0 \pm 0.6^{* * *}$ \\
\hline $\operatorname{IgM~V}_{\mathrm{H}} 6^{+}$ & $0.7 \pm 0.6$ \\
\hline $\operatorname{IgM~V} \mathrm{V}_{\mathrm{H}} 6^{+}+$Protein $\mathrm{A}$ & $18.7 \pm 0.3$ \\
\hline
\end{tabular}

Protein A $(300 \mathrm{nM})$ was preincubated $\left(15 \mathrm{~min}\right.$ at $\left.37^{\circ} \mathrm{C}\right)$ with $\operatorname{IgM~V} \mathrm{V}_{\mathrm{H}} 3^{+}(10 \mu \mathrm{g} / \mathrm{mL})$ or $\operatorname{IgM~V} \mathrm{V}_{\mathrm{H}} 6^{+}(10 \mu \mathrm{g} / \mathrm{mL})$ and incubation continued for another $45 \mathrm{~min}$ at $37^{\circ} \mathrm{C}$. Results show the mean $\pm \mathrm{SEM}$ of percent histamine release obtained from three experiments with different preparations of HLMCs. ${ }^{* * *} p<0.001$ when compared to protein A alone. 
(A)

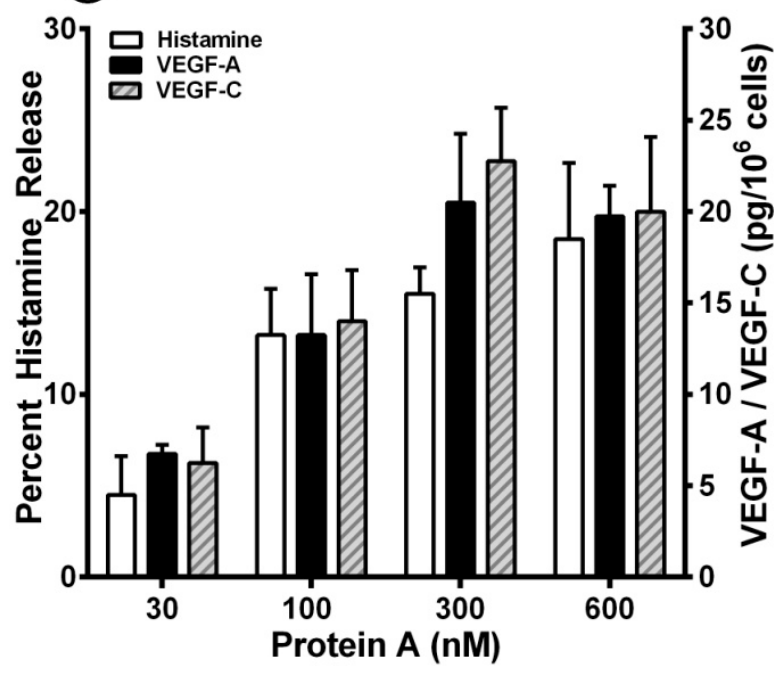

(C)

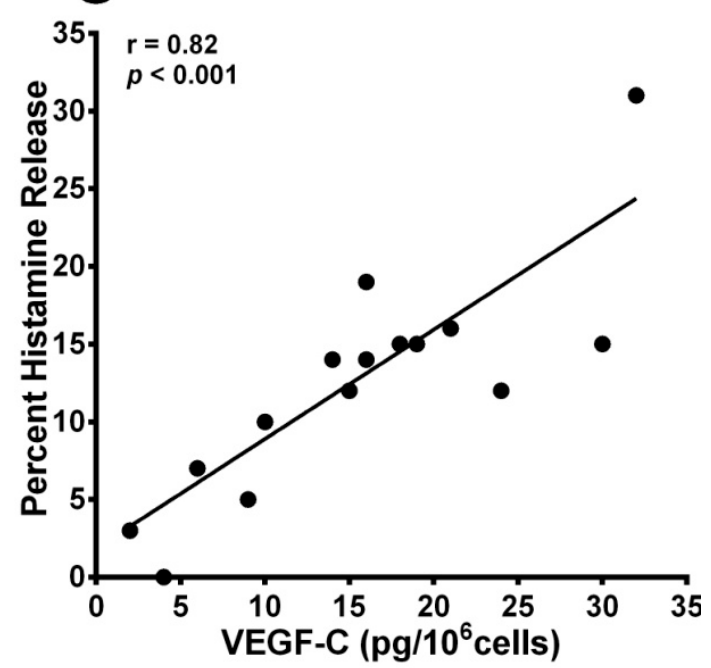

(B)

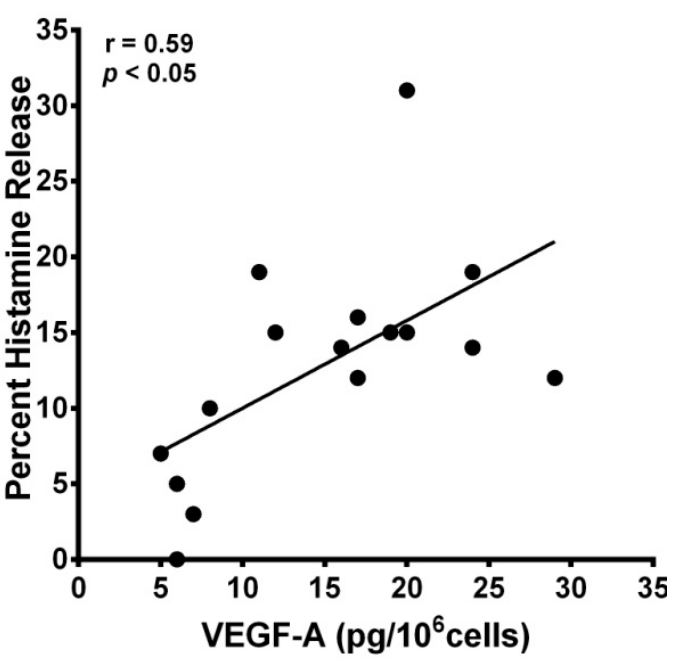

(D)

Protein A

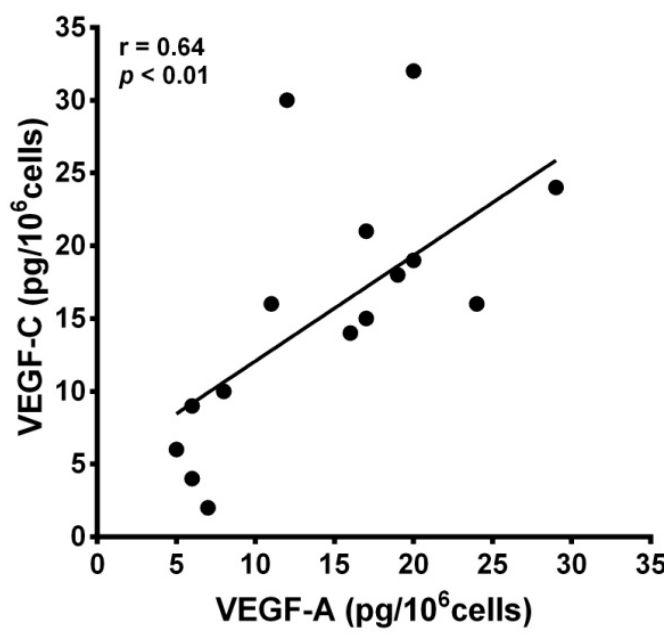

Figure 2. (A) Effects of increasing concentrations of protein A on histamine release and the production of VEGF-A and VEGF-C from four different preparations of human lung mast cells (HLMCs). HLMCs were incubated (45 min at $37^{\circ} \mathrm{C}$ ) with the indicated concentrations of protein A for histamine secretion or $\left(12 \mathrm{~h}\right.$ at $\left.37^{\circ} \mathrm{C}\right)$ for VEGF-A and VEGF-C release. Each bar is the mean \pm SEM; (B) Correlation $(r=0.59 ; p<0.05)$ between VEGF-A release and the percent histamine secretion caused by protein A from HLMCs; $(C)$ Correlation $(r=0.82 ; p<0.001)$ between VEGF-C release and the percent histamine secretion caused by protein A from HLMCs; (D) Correlation $(\mathrm{r}=0.64 ; p<0.01)$ between VEGF-A and VEGF-C release caused by protein A from HLMCs from HLMCs.

There was a significant correlation between the release of VEGF-A and histamine secretion $(\mathrm{r}=0.59 ; p<0.05)$ caused by protein A (Figure $2 \mathrm{~B})$. In addition, there was a significant correlation between VEGF-C production and histamine secretion $(\mathrm{r}=0.82$; $p<0.001)$ (Figure 2C) and between VEGF-A and VEGF-C production $(\mathrm{r}=0.64 ; p<0.01)$ (Figure 2D).

\subsection{Effects of IL-33 on the Release of Angiogenic and Lymphangiogenic Factors from HLMCs}

Several investigators have found that IL-33 can induce the release of different cytokines from human cord blood (CBMCs) and peripheral blood-derived mast cells (PBMCs) [17,68-71,78,99]. By contrast, IL-33 had no effect on the release of preformed mediators from mouse and human mast cells [100]. Interestingly, long-term incubation of human skin mast cells (HSMCs) with IL-33 reduced anti-IgE-induced histamine secretion 
from human skin mast cells (HSMCs) [68], whereas short-term exposure of HSMCs synergistically potentiated $\beta$-hexosaminidase release induced by substance $\mathrm{P}(\mathrm{SP})$ and anti-IgE [74]. Figure $3 \mathrm{~A}$ shows that IL-33 (10 to $100 \mathrm{ng} / \mathrm{mL}$ ) caused a concentration-dependent release of both VEGF-A and VEGF-C from HLMCs. By contrast, short-term incubation of HLMCs with IL-33 did not induce histamine release from these cells. The maximum VEGF-A release induced by IL-33 was significantly lower than that caused by both anti-IgE $\left(12.7 \pm 1.7 \mathrm{pg} / 10^{6}\right.$ cells vs. $52.3 \pm 3.3 \mathrm{pg} / 10^{6}$ cells; $\left.p<0.001\right)$ and protein A $\left(12.7 \pm 1.7 \mathrm{pg} / 10^{6}\right.$ cells vs. $24.3 \pm 1.9 \mathrm{pg} / 10^{6}$ cells; $\left.p<0.01\right)$. Similarly, the maximum release of VEGF-C induced by IL-33 was lower than that caused by anti-IgE $\left(12.3 \pm 2.1 \mathrm{pg} / 10^{6}\right.$ cells vs. $49.0 \pm 5.9 \mathrm{pg} / 10^{6}$ cells; $p<0.01)$ and protein A $\left(12.3 \pm 2.1 \mathrm{pg} / 10^{6}\right.$ cells vs. $26.8 \pm 2.6 \mathrm{pg} / 10^{6}$ cells; $\left.p<0.01\right)$. There was no correlation between the production of both VEGF-A (Figure 3B) and VEGF-C (Figure 3C) and histamine release induced by IL-33 from HLMCs. By contrast, there was a significant correlation between the release of VEGF-A and VEGF-C $(r=0.91 ; p<0.001)$ induced by IL-33 from HLMCs (Figure 3D).
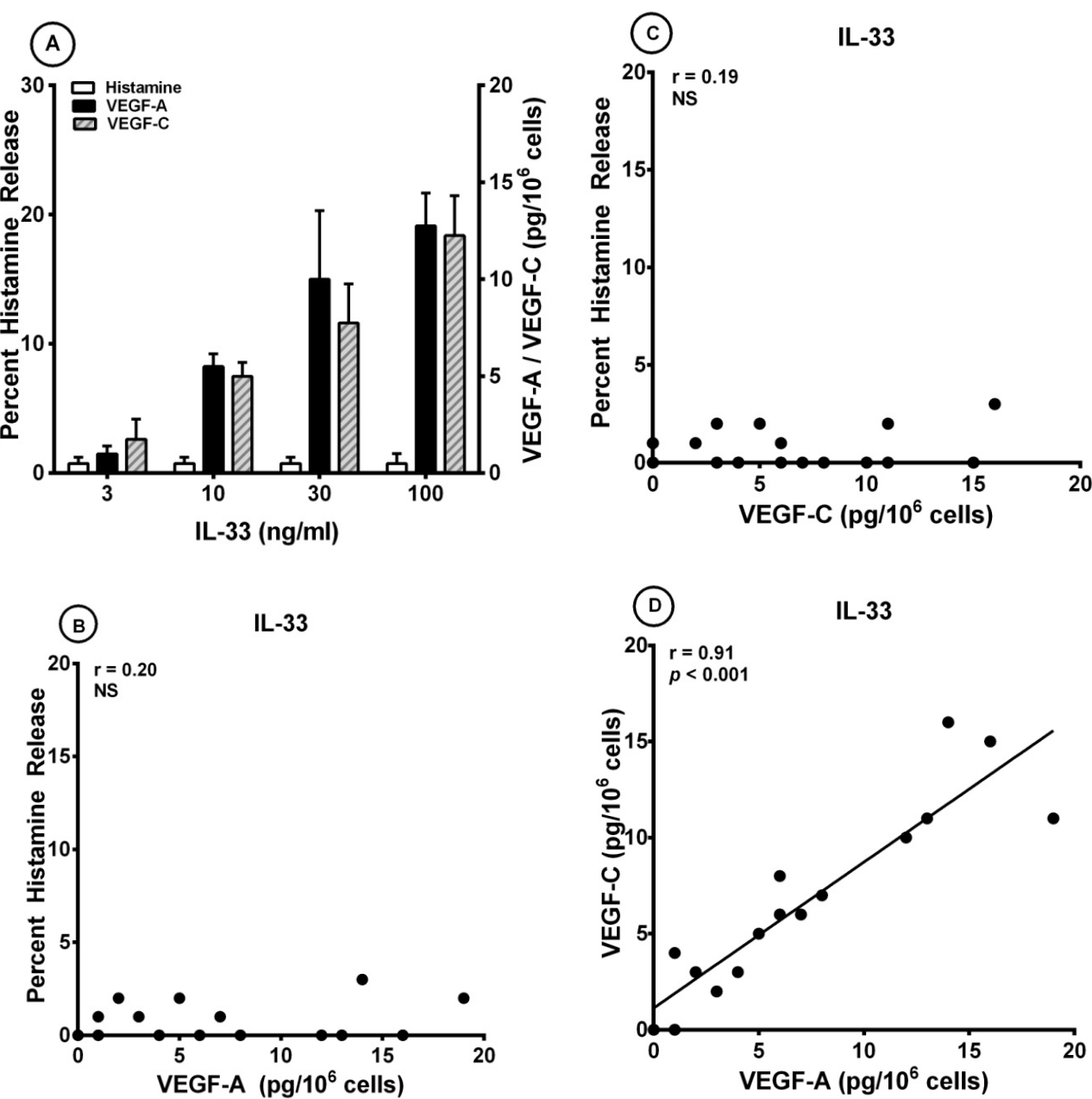

Figure 3. (A) Effects of increasing concentrations of IL-33 on histamine release and the production of VEGF-A and VEGF-C from four different preparations of human lung mast cells (HLMCs). HLMCs were incubated $\left(45 \mathrm{~min}\right.$ at $\left.37^{\circ} \mathrm{C}\right)$ with the indicated concentrations of IL-33 for histamine secretion or $\left(12 \mathrm{~h}\right.$ at $\left.37^{\circ} \mathrm{C}\right)$ for VEGF-A and VEGF-C release. Each bar is the mean \pm SEM; (B) Lack of correlation ( $\mathrm{r}=0.20$; NS) between VEGF-A release and the percent histamine secretion caused by IL-33 from HLMCs; (C) Lack of correlation ( $\mathrm{r}=0.19$; NS) between VEGF-C release and the percent histamine secretion caused by IL-33 from HLMCs; (D) Correlation ( $r=0.91 ; p<0.001)$ between VEGF-A and VEGF-C release caused by IL-33 from HLMCs. 


\subsection{Effect of Short-Term Priming by IL-33 on Superantigenic Release of Mediators from HLMCs}

It has been reported that short-term priming by IL-33 can potentiate the release of cytokines induced by different stimuli from mouse [73] and human mast cells $[17,20,69,71,74,101]$. In a series of experiments, HLMCs were preincubated $\left(30 \mathrm{~min}, 37^{\circ} \mathrm{C}\right)$ with IL-33 $(30 \mathrm{ng} / \mathrm{mL})$ before exposure to protein A $(100 \mathrm{nM})$. The results presented in Figure $4 \mathrm{~A}$ confirm that IL-33 alone has no effect on histamine release whereas it induced both VEGF-A (Figure 4B) and VEGF-C (Figure 4C) from HLMCs. Interestingly, short-term priming by IL-33 potentiated the release of VEGF-A (Figure 4B) and VEGF-C (Figure 4C) induced by protein A from HLMCs.
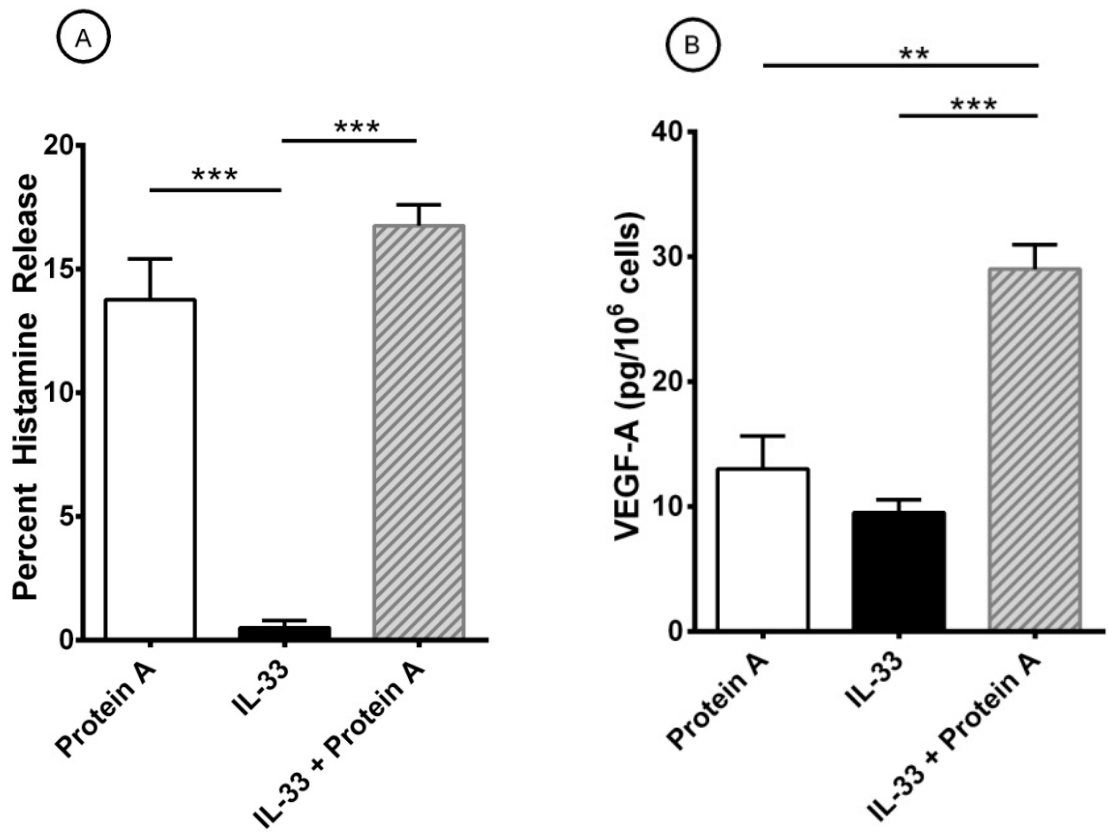

(C)
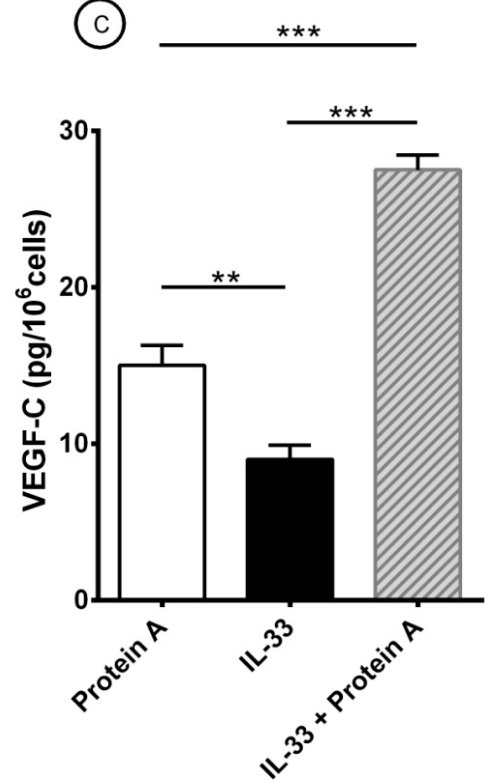

Figure 4. Effects of short-term priming by IL-33 an protein A-induced release of histamine (A), VEGF-A (B), and VEGF-C (C) from HLMCs. Mast cells were preincubated $\left(30 \mathrm{~min}\right.$ at $\left.37^{\circ} \mathrm{C}\right)$ with IL-33 $(30 \mathrm{ng} / \mathrm{mL})$ before exposure to protein A $(100 \mathrm{nM})$. After $45 \mathrm{~min}$ incubation at $37^{\circ} \mathrm{C}$, HLMCs were harvested, centrifuged, and histamine release measured in the supernatants. For the evaluation of VEGFs, HLMCs were incubated for $12 \mathrm{~h}$ at $37^{\circ} \mathrm{C}$. At the end of incubation, cells were harvested, centrifuged and VEGF-A and VEGF-C measured in the supernatants. Results show the mean \pm SEM obtained in three experiments. ${ }^{* *} p<0.01 ;{ }^{* * *} p<0.001$. 
Protein $\mathrm{L}$ is another immunoglobulin $\mathrm{SAg}$, which binds to human Igs through a mechanism different from protein $\mathrm{A}[45,102]$. This protein binds with high affinity $\left(\sim 10^{10} \mathrm{M}^{-1}\right)$ only to subtypes $\left(\mathrm{V}_{\mathrm{K}} \mathrm{I}, \mathrm{V}_{\mathrm{K}} \mathrm{III}\right.$, and $\left.\mathrm{V}_{\mathrm{K}} \mathrm{IV}\right)$ of $\mathrm{k}$ light chains of human Igs, including $\operatorname{IgE}[46,48,49]$. We have found that protein $\mathrm{L}$ is a superantigenic stimulus inducing the release of preformed and the de novo synthesized inflammatory mediators from human cardiac mast cells through the interaction with $\mathrm{k}$ light chains of IgE [98]. In a series of preliminary experiments, we found that increasing concentrations (1-300 $\mathrm{nM}$ ) of protein $\mathrm{L}$ caused the release of inflammatory mediators from HLMCs (data not shown). Table 4 shows that protein L (100 nM) induced histamine release from HLMCs. Preincubation of protein L with increasing concentrations (0-3-1 $\mu \mathrm{g} / \mathrm{mL}$ ) of human monoclonal $\operatorname{IgE} \lambda$ light chain did not modify the activating property of protein L. By contrast, preincubation with the same concentrations of human monoclonal $\mathrm{IgE} \kappa$ light chain concentration-dependently inhibits the release of histamine induced by protein L from HLMCs. These results are compatible with the hypothesis that protein L activates HLMCs through the interaction with the $\mathrm{k}$ light chain of IgE on lung mast cells. We then examined the interactions between protein L and IL-33 on the activation of HLMCs. Figure 5 shows the results of a typical experiment showing that protein $\mathrm{L}$ induces the release of histamine from HLMCs (Figure 5A). By contrast, IL-33 did not induce histamine secretion from HLMCs (Figure 5A) but caused a small production of VEGF-A (Figure 5B) and VEGF-C (Figure 5C). Short-term incubation (30 $\mathrm{min}, 37^{\circ} \mathrm{C}$ ) of HLMCs with IL-33 $(30 \mathrm{mg} / \mathrm{mL}$ ) potentiated the secretion of histamine (Figure 5A) and the release of VEGF-A (Figure 5B) and VEGF-C (Figure 5C) induced by protein $\mathrm{L}$ from HLMCs. Similar results were obtained in two additional experiments with different preparations of HLMCs (data not shown).

Table 4. Effects of preincubation of protein $L$ with human monoclonal $\operatorname{Ig} E \lambda$ or $\operatorname{IgE} \kappa$ on the activation of HLMCs.

\begin{tabular}{cc}
\hline Stimulus & Percent Histamine Release \\
\hline Protein $\mathrm{L}(100 \mathrm{nM})$ & $19.0 \pm 1.5$ \\
$\operatorname{IgE} \lambda(0.3 \mu \mathrm{g} / \mathrm{mL})+$ Protein $\mathrm{L}$ & $18.7 \pm 1.8$ \\
$\operatorname{IgE} \lambda(1 \mu \mathrm{g} / \mathrm{mL})+$ Protein $\mathrm{L}$ & $18.3 \pm 2.0$ \\
$\operatorname{IgE} \kappa(0.3 \mu \mathrm{g} / \mathrm{mL})+$ Protein $\mathrm{L}$ & $13.7 \pm 0.7^{*}$ \\
$\operatorname{IgE} \kappa(1 \mu \mathrm{g} / \mathrm{mL})+$ Protein $\mathrm{L}$ & $3.7 \pm 1.2^{* *}$ \\
\hline
\end{tabular}

Protein L $(100 \mathrm{nM})$ was preincubated $\left(15 \mathrm{~min}\right.$ at $\left.37^{\circ} \mathrm{C}\right)$ with increasing concentrations $(0.3 \mathrm{or} 1 \mu \mathrm{g} / \mathrm{mL})$ of human monoclonal IgE $\lambda$ light chain or human monoclonal IgE $\kappa$ light chain, and incubation continued for another $45 \mathrm{~min}$ at $37^{\circ} \mathrm{C}$. Results show the mean \pm SEM of triplicate determinations of percent histamine release. Similar results were obtained in another experiment. ${ }^{*} p<0.05$ when compared to protein L alone. ${ }^{* *} p<0.01$ when compared to protein L alone.

\section{Discussion}

Primary mast cells isolated from human lung parenchyma can be activated by a human IgG anti-IgE isolated from a patient with atopic dermatitis to release histamine, VEGF-A, and VEGF-C. Similar results were obtained by activating HLMCs with a monoclonal antibody anti-FceRI. These findings indicate that HLMCs expressing FceRI bind IgE, which is a central immunoglobulin in the pathogenesis of several allergic disorders [103,104] and pulmonary diseases $[6,13]$. Two bacterial superantigens, protein $A$ and protein $\mathrm{L}$, which bind to distinct regions of human IgE [43-45,49], activate HLMCs to release inflammatory (histamine), angiogenic (VEGF-A) and lymphangiogenic (VEGF-C) factors. IL-33, expressed and released by lung epithelial cells and endothelial cells $[63,77]$, does not induce histamine release from HLMCs, but potentiates the release of VEGF-A and VEGF-C induced by superantigens from HLMCs. 

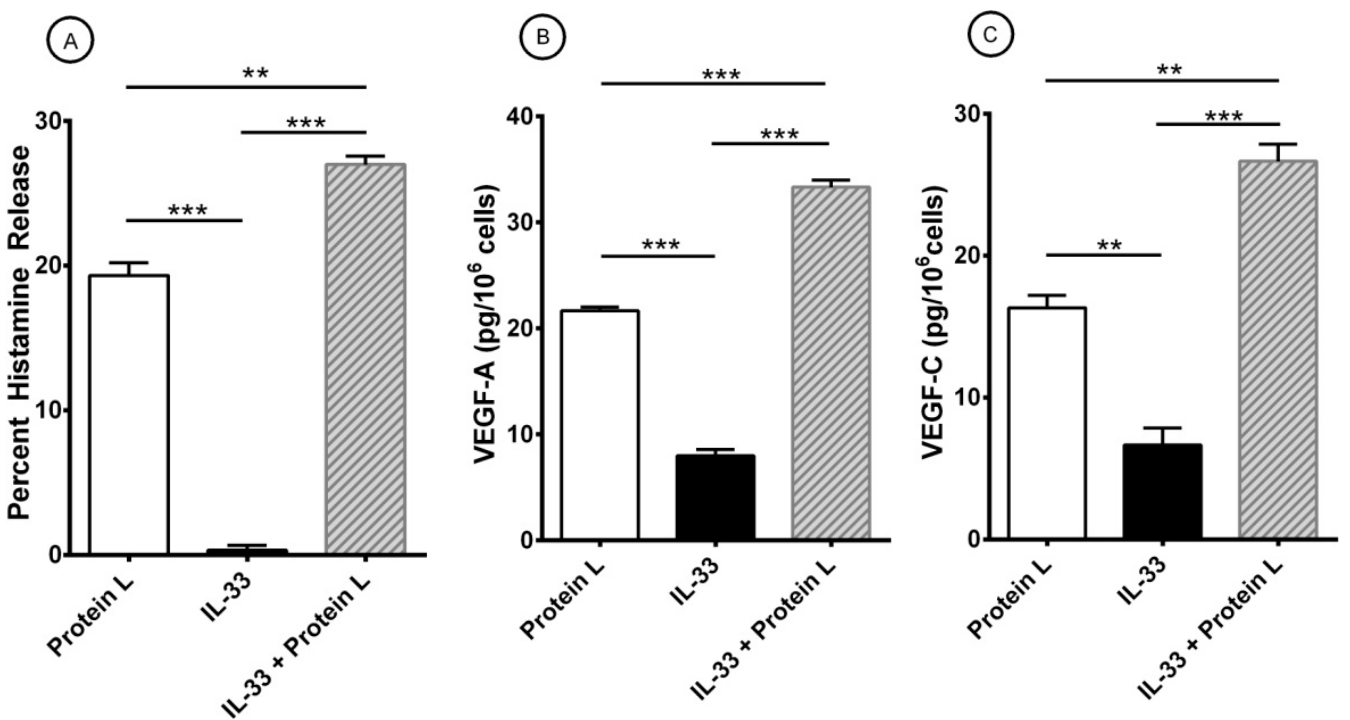

Figure 5. Effects of short-term priming by IL-33 and protein L-induced release of histamine (A), VEGF-A (B), and VEGF-C (C) from HLMCs. Mast cells were preincubated $\left(30 \mathrm{~min}\right.$ at $\left.37^{\circ} \mathrm{C}\right)$ with IL-33 $(30 \mathrm{ng} / \mathrm{ml})$ before exposure to protein L $(100 \mathrm{nM})$. After $45 \mathrm{~min}$ incubation at $37^{\circ} \mathrm{C}, \mathrm{HLMCs}$ were harvested, centrifuged, and histamine release measured in the supernatants. For the evaluation of VEGFs, HLMCs were incubated for $12 \mathrm{~h}$ at $37^{\circ} \mathrm{C}$. At the end of incubation, cells were harvested, centrifuged and VEGF-A and VEGF-C measured in the supernatants. Results show the mean \pm SEM of triplicate determinations obtained in a typical experiment. ${ }^{* *} p<0.01 ;{ }^{* * *} p<0.001$.

Mast cells are strategically located in different compartments of human lung [3,4,78]. These cells and their mediators play a central role in the pathophysiology of bronchial asthma [1,2,9], lung remodeling [105], angiogenesis [14,16,17,98], lymphangiogenesis [14,18,94,98], chronic obstructive pulmonary disease (COPD) [106], and lung cancer [107,108].

Asthma is a heterogeneous syndrome that has been subdivided into phenotypes and molecular endotypes [109]. Type 2 (T2)-high subtype asthma is characterized by IgE-mediated activation of lung mast cells and includes the majority of asthmatic patients $[103,104]$. T2-low asthma is less well-characterized and presumably includes different clinical and genetic variants [110,111]. T2-low asthma may be driven by abnormal neuronal activation, structural abnormalities involving airway smooth muscle as well as bacterial and viral superantigens $[112,113]$. We found that cross-linking the IgE-FceRI network on HLMCs induces the release of histamine. More importantly, we found that IgE-mediated activation of primary HLMCs also induces the production of VEGF-A and VEGF-C. The latter findings extend previous results indicating that activation of different types of human mast cells causes the release of VEGF-A [14,16,17,94,98]. Interestingly, IgE-mediated activation of HLMCs induces the release of VEGF-C, which is the most potent lymphangiogenic factor $[114,115]$.

Several investigators have provided evidence that bacterial superantigens play a role in different allergic disorders [40,116]. We found that low concentrations of Staphylococcal protein A induces the release of histamine, VEGF-A, and VEGF-C from HLMCs. These findings might be relevant to explain the role of bacterial superantigens in the pathogenesis of various allergic disorders. The role of $S$. aureus in the pathogenesis of allergic diseases has been attributed to its capacity to activate $\mathrm{T}$ and $\mathrm{B}$ cells, resulting in cell proliferation and massive cytokine release [117]. On the other hand, it has been shown that Staphylococcal superantigens can induce the formation of $\operatorname{IgE}$ antibodies $[95,118]$ and the presence of specific $\operatorname{IgE}$ has been associated with the severity of airway and skin allergic disorders $[52,119,120]$. There is also evidence that $S$. aureus can trigger the production of cytokines from human mast cells through the engagement of TLR2 and CD48 molecules [97]. Our results indicate that protein A might contribute to the role played by S. aureus in allergic diseases by induc- 
ing the release of histamine and angiogenic and lymphangiogenic factors from HLMCs through the interaction with the $\mathrm{V}_{\mathrm{H}} 3$ region of IgE.

Protein L is another Ig superantigen which specifically interacts with high affinity with the $k$ light chains of human Igs, including IgE [42]. In this study, we found that protein $\mathrm{L}$ is a potent stimulus to induce the secretion of histamine and the release of VEGF-A and VEGF-C from HLMCs. These results extend previous findings indicating that protein $\mathrm{L}$ induced the release of preformed (i.e., histamine) and de novo synthesized mediators (i.e., prostaglandin $\mathrm{D}_{2}$ : $\mathrm{PGD}_{2}$ ) from human cardiac mast cells [98]. Collectively, these findings indicate that protein $\mathrm{L}$ is a complete mast cell secretagogue capable of releasing inflammatory, angiogenic and lymphangiogenic mediators implicated in cardio-pulmonary pathophysiology [121-123].

Recent studies revealed that cytokines such as thymic stromal lymphopoietin (TSLP) [124-126], IL-33 [78,99,127-129], and IL-25 [130], highly expressed in the airway epithelium, are implicated in human asthma [131]. These upstream cytokines serve as key regulators of T2-high and T2-low asthma [99,128,132]. In particular, IL-33 is overexpressed by epithelial cells in bronchial asthma [129] and activates different types of rodent $[70,73,133]$ and human mast cells $[17,20,68,69,71,72,74]$. There is some evidence that IL-33, but not TSLP or IL-25, is central in models of allergic sensitization [78,127]. In this study, short-term incubation of HLMCs with IL-33 does not induce the secretion of histamine, confirming the results of previous studies [99]. By contrast, it has been reported that long-term $(24 \mathrm{~h})$ incubation of HLMCs with IL-33 caused marginal, but significant histamine release [99].

IL-33 can induce the production of several cytokines from mouse $[70,73,133]$, human CBMCs $[17,78]$ and PBMCs $[20,69,72]$, mast cell lines [17,71], and primary mast cells [99]. We extended these findings by showing that IL-33 alone induces the release of angiogenic VEGF-A and lymphangiogenic VEGF-C from HLMCs. The activating property of IL-33 is likely mediated by the engagement of IL-33 receptor (ST2), which is highly expressed by human mast cells [72,99].

Angiogenesis plays a role in pulmonary pathophysiology $[18,134,135]$. VEGF-A is a major mediator of angiogenesis and can be produced by several immune cells $[14,36,37,136,137]$. To our knowledge, this is the first evidence that superantigens protein $\mathrm{A}$ and protein $\mathrm{L}$ induce the release of angiogenic factors from HLMCs raising the possibility that these cells can contribute to angiogenesis, a process of pivotal relevance in bronchial asthma $[18,134]$ and lung cancer [135]. Further studies are needed to comprehensively define the contributive role of IL-33 and superantigens to angiogenesis in pulmonary disorders.

The mammalian lung is rich in lymphatic vessels [138] which are increased in human lung following infections [139-141]. We provide the first evidence that a superantigenic activation of HLMCs leads to the production of VEGF-C, a major mediator of lymphangiogenesis [142]. Lymphangiogenesis is canonically considered pivotal for the diffusion of metastasis to draining lymph nodes $[143,144]$. However, recent evidences indicate that VEGF-C can potentially exert protective effects, since inflammation-associated lymphangiogenesis can improve the resolution of inflammation $[115,145]$. Therefore, the contribution of bacterial superantigens to lung mast cell-mediated lymphangiogenesis requires additional investigations.

To the best of our knowledge, we provide the first evidence that IL-33 can induce the release of the lymphangiogenic factor VEGF-C from HLMCs. This finding extends a previous observation indicating that immunologically-activated human cardiac mast cells release VEGF-C [98]. The production of VEGF-C by activated primary human mast cells is intriguing because these cells are at the interface of the lymphatic and immune systems [146]. In several clinical and experimental studies, mast cells play a pro-tumorigenic role, whereas in others, they play an anti-tumorigenic role $[25,26,143,147]$. VEGF-C is mostly viewed as the most potent lymphangiogenic factor [115] controlling the formation of metastasis. However, increasing evidences indicate that, under certain circumstances, lymphangiogenesis and VEGF-C have protective effects in cancer [148]. Moreover, VEGF-C 
can exert a protective role in several inflammatory disorders $[149,150]$ by favoring the resolution of inflammation [142,151,152]. The pathophysiological role of VEGF-C released by human lung and cardiac mast cells [98] deserves further investigations.

Several studies have provided evidence that IL-33 can exert a priming effect on the activation of rodent [73] and human mast cells $[17,20,69,71,74]$. A previous study reported that preincubation of LAD2 cells and CBMCs with IL-33 augmented SP-induced VEGF-A mRNA and VEGF-A protein secretion [17]. In our study, we found that shortterm incubation of HLMCs with IL-33 potentiates the release of histamine, VEGF-A, and VEGF-C induced by superantigens protein $A$ and protein $\mathrm{L}$. The interactions between IL-33 and IgE-mediated stimuli (i.e., protein A and protein L) is unlikely mediated by an overexpression of FcERI because it has been demonstrated that IL-33 does not increase FceRI expression on human mast cells [74].

IL-33 is an alarmin overexpressed in lung epithelial cells [99,129] in asthmatic patients. IL-33 expression has been also identified in human airway smooth muscle (ASM) and HLMCs in mild-to-moderate asthma [99]. Using quantitative morphometry of the airway wall, it has been demonstrated that IL-33 causes a shift in mast cells from the submucosa to the airway epithelium associated with type 2 inflammation and airway hyperresponsiveness (AHR) [78]. A recent study highlighted a novel pathogenetic mechanism of interaction between IL-33 and S. aureus as inducers of airway inflammation in mice [118]. Intratracheal exposure to $S$. aureus derived serine protease-like protein (Spl) D upregulated IL-33 production in the lung leading to eosinophilia, bronchial hyperreactivity, and goblet cell hyperplasia in the airways. Interestingly, blocking IL-33 activity with a soluble ST2 receptor significantly reduced airway inflammation. Our findings highlight a novel immunologic mechanism by which IL-33 and superantigen protein A can amplify the immune response in inflammatory disorders involving lung mast cells. Collectively, these findings might have translational relevance emphasizing the relevance of IL-33/S. aureus-derived proteins in inducing inflammatory response in the airways $[78,99,153]$. The translational significance of the interactions between IL-33 and bacterial superantigens deserves further investigations in experimental models of asthma.

Our study has several limitations that should be pointed out. The in vitro experiments were performed using primary mast cells purified from lung parenchyma of patients undergoing thoracic surgery for lung cancer. The purity of HLMCs used in these experiments ranged from $49 \%$ to $81 \%$. Although the activating properties of protein $\mathrm{A}$, protein $\mathrm{L}$ and IL-33 were not affected by mast cell purity, we cannot exclude the possibility that contaminating cells may have influenced some of our results. In addition, IL-33 is released by tumor cells [84] and by a myriad of immune and non-immune cells localized in human lung [64]. There is the possibility that in vivo exposure of HLMCs to IL-33 could explain some of our results. In addition, HLMCs, although obtained from macroscopically normal lung tissue, are in close proximity to lung cancer cells. There is the possibility that the in vivo exposure to altered tumor microenvironment, such as low $\mathrm{pH}$ [154], hypoxia [155,156], lactate [157], or adenosine $[37,158,159]$, may have affected the phenotypic expression and the functional activity of pulmonary mast cells.

In conclusion, our results indicate that two immunoglobulin superantigens, protein $\mathrm{A}$ and protein $\mathrm{L}$, can interact with different domains of human $\operatorname{IgE}$ bound to FceRI to induce the release of inflammatory, angiogenic and lymphangiogenic factors from human lung mast cells. IL-33 synergistically potentiates the superantigenic release of mediators from these cells. Future studies are needed to investigate whether these in vitro observations can help to understand the in vivo interactions between IL-33 and S. aureus in inflammatory airway disorders.

Author Contributions: Conceptualization, M.R.G., S.L., A.d.P., G.M. and G.V.; formal analysis, G.C., G.M. and G.V.; investigation, L.C., R.P., A.L.F. and L.M.; data curation, G.C. and G.V.; writingoriginal draft preparation, L.C., R.P. and G.S.; writing-review and editing, G.C., G.M. and G.V.; supervision, G.M. and G.V.; funding acquisition, M.R.G., G.M., G.S. and G.V. All authors have read and agreed to the published version of the manuscript. 
Funding: This research was funded in part by grants from Regione Campania CISI-Lab Project, TIMING Project, Campania Bioscience and MIUR PRIN 2017 M8Y MR8_005.

Institutional Review Board Statement: The study was conducted according to the guidelines of the Declaration of Helsinki, and approved by the Ethics Committee of the University of Naples Fed-erico II (Protocol: Human MC No. 7/19).

Informed Consent Statement: Informed consent was obtained from all subjects involved in the study.

Data Availability Statement: The data presented in this study are available on request from the corresponding author.

Acknowledgments: We are grateful to all patients for donating their samples.

Conflicts of Interest: The authors declare no conflict of interest.

$\begin{array}{ll}\text { Abbreviations } \\ \text { AHR } & \text { Airway hyperresponsiveness } \\ \text { ASM } & \text { Airway smooth muscle } \\ \text { BSA } & \text { Bovine serum albumin } \\ \text { COPD } & \text { Chronic obstructive pulmonary disease } \\ \text { CBMC } & \text { Cord blood-derived mast cell } \\ \text { FceRI } & \text { High-affinity receptor for IgE } \\ \text { FCS } & \text { Fetal calf serum } \\ \text { H } & \text { Heavy } \\ \text { H-aIgE } & \text { Human IgG anti-IgE } \\ \text { HLMC } & \text { Human lung mast cell } \\ \text { Ig } & \text { Immunoglobulin } \\ \text { IL-33 } & \text { Interleukin-33 } \\ \text { IL } & \text { Interleukin } \\ \text { L } & \text { Light } \\ \text { LTC } & \text { Cysteinyl leukotriene } C_{4} \\ \text { mAb } & \text { Monoclonal antibody } \\ \text { P. magnus } & \text { Peptostreptococcus magnus } \\ \text { PBMC } & \text { Peripheral blood-derived mast cell } \\ \text { PGD } & \text { Prostaglandin } D_{2} \\ \text { S. aureus } & \text { Staphylococcus aureus } \\ \text { SAg } & \text { Superantigen } \\ \text { SE } & \text { Staphylococcus aureus enterotoxins } \\ \text { SP } & \text { Substance P } \\ \text { TCR } & \text { T cell receptor } \\ \text { Treg } & \text { regulatory T cell } \\ \text { TSLP } & \text { Thymic stromal lymphopoietin } \\ \text { V } & \text { Variable } \\ \text { VEGF } & \text { Vascular endothelial growth factor } \\ & \end{array}$

\section{References}

1. Varricchi, G.; Rossi, F.W.; Galdiero, M.R.; Granata, F.; Criscuolo, G.; Spadaro, G.; de Paulis, A.; Marone, G. Physiological Roles of Mast Cells: Collegium Internationale Allergologicum Update 2019. Int. Arch. Allergy Immunol. 2019, 179, 247-261. [CrossRef]

2. Borriello, F.; Granata, F.; Varricchi, G.; Genovese, A.; Triggiani, M.; Marone, G. Immunopharmacological Modulation of Mast Cells. Curr. Opin. Pharmacol. 2014, 17, 45-57. [CrossRef]

3. Casolaro, V.; Galeone, D.; Giacummo, A.; Sanduzzi, A.; Melillo, G.; Marone, G. Human Basophil/Mast Cell Releasability. V. Functional Comparisons of Cells Obtained from Peripheral Blood, Lung Parenchyma, and Bronchoalveolar Lavage in Asthmatics. Am. Rev. Respir. Dis. 1989, 139, 1375-1382. [CrossRef] [PubMed]

4. Zilionis, R.; Engblom, C.; Pfirschke, C.; Savova, V.; Zemmour, D.; Saatcioglu, H.D.; Krishnan, I.; Maroni, G.; Meyerovitz, C.V.; Kerwin, C.M.; et al. Single-Cell Transcriptomics of Human and Mouse Lung Cancers Reveals Conserved Myeloid Populations across Individuals and Species. Immunity 2019, 50, 1317-1334.e10. [CrossRef] [PubMed]

5. Olivera, A.; Beaven, M.A.; Metcalfe, D.D. Mast Cells Signal Their Importance in Health and Disease. J. Allergy Clin. Immunol. 2018, 142, 381-393. [PubMed] 
6. Piliponsky, A.M.; Romani, L. The Contribution of Mast Cells to Bacterial and Fungal Infection Immunity. Immunol. Rev. 2018, 282, 188-197. [CrossRef] [PubMed]

7. Varricchi, G.; Raap, U.; Rivellese, F.; Marone, G.; Gibbs, B.F. Human Mast Cells and Basophils-How Are They Similar How Are They Different? Immunol. Rev. 2018, 282, 8-34. [CrossRef] [PubMed]

8. Mukai, K.; Tsai, M.; Saito, H.; Galli, S.J. Mast Cells as Sources of Cytokines, Chemokines, and Growth Factors. Immunol. Rev. 2018, 282, 121-150. [CrossRef]

9. Bradding, P.; Arthur, G. Mast Cells in Asthma-State of the Art. Clin. Exp. Allergy 2016, 46, 194-263.

10. Marone, G.; Varricchi, G.; Loffredo, S.; Galdiero, M.R.; Rivellese, F.; de Paulis, A. Are Basophils and Mast Cells Masters in Hiv Infection? Int. Arch. Allergy Immunol. 2016, 171, 158-165.

11. Suurmond, J.; Rivellese, F.; Dorjee, A.L.; Bakker, A.M.; Rombouts, Y.J.; Rispens, T.; Wolbink, G.; Zaldumbide, A.; Hoeben, R.C.; Huizinga, T.W.; et al. Toll-Like Receptor Triggering Augments Activation of Human Mast Cells by Anti-Citrullinated Protein Antibodies. Ann. Rheum. Dis. 2015, 74, 1915-1923. [CrossRef]

12. Piliponsky, A.M.; Acharya, M.; Shubin, N.J. Mast Cells in Viral, Bacterial, and Fungal Infection Immunity. Int. J. Mol. Sci. 2019, 20, 2851. [CrossRef]

13. Voehringer, D. Protective and Pathological Roles of Mast Cells and Basophils. Nat. Rev. Immunol. 2013, 13, 362-375. [CrossRef]

14. Detoraki, A.; Staiano, R.I.; Granata, F.; Giannattasio, G.; Prevete, N.; de Paulis, A.; Ribatti, D.; Genovese, A.; Triggiani, M.; Marone, G. Vascular Endothelial Growth Factors Synthesized by Human Lung Mast Cells Exert Angiogenic Effects. J. Allergy Clin. Immunol. 2009, 123, 1142-1149. [CrossRef]

15. Varricchi, G.; Loffredo, S.; Galdiero, M.R.; Marone, G.; Cristinziano, L.; Granata, F. Innate Effector Cells in Angiogenesis and Lymphangiogenesis. Curr. Opin. Immunol. 2018, 53, 152-160. [CrossRef]

16. Marone, G.; Varricchi, G.; Loffredo, S.; Granata, F. Mast Cells and Basophils in Inflammatory and Tumor Angiogenesis and Lymphangiogenesis. Eur. J. Pharmacol. 2016, 778, 146-151. [CrossRef]

17. Theoharides, T.C.; Zhang, B.; Kempuraj, D.; Tagen, M.; Vasiadi, M.; Angelidou, A.; Alysandratos, K.D.; Kalogeromitros, D.; Asadi, S.; Stavrianeas, N.; et al. Il-33 Augments Substance P-Induced Vegf Secretion from Human Mast Cells and Is Increased in Psoriatic Skin. Proc. Natl. Acad. Sci. USA 2010, 107, 4448-4453. [CrossRef]

18. Detoraki, A.; Granata, F.; Staibano, S.; Rossi, F.W.; Marone, G.; Genovese, A. Angiogenesis and Lymphangiogenesis in Bronchial Asthma. Allergy 2010, 65, 946-958.

19. Varricchi, G.; Granata, F.; Loffredo, S.; Genovese, A.; Marone, G. Angiogenesis and Lymphangiogenesis in Inflammatory Skin Disorders. J. Am. Acad. Dermatol. 2015, 73, 144-153. [CrossRef]

20. Rivellese, F.; Suurmond, J.; Habets, K.; Dorjee, A.L.; Ramamoorthi, N.; Townsend, M.J.; de Paulis, A.; Marone, G.; Huizinga, T.W.; Pitzalis, C.; et al. Ability of Interleukin-33- and Immune Complex-Triggered Activation of Human Mast Cells to Down-Regulate Monocyte-Mediated Immune Responses. Arthritis Rheumatol. 2015, 67, 2343-2353. [CrossRef]

21. Rivellese, F.; Nerviani, A.; Rossi, F.W.; Marone, G.; Matucci-Cerinic, M.; de Paulis, A.; Pitzalis, C. Mast Cells in Rheumatoid Arthritis: Friends or Foes? Autoimmun. Rev. 2017, 16, 557-563. [CrossRef] [PubMed]

22. Rivellese, F.; Mauro, D.; Nerviani, A.; Pagani, S.; Fossati-Jimack, L.; Messemaker, T.; Kurreeman, F.A.S.; Toes, R.E.M.; Ramming, A.; Rauber, S.; et al. Mast Cells in Early Rheumatoid Arthritis Associate with Disease Severity and Support B Cell Autoantibody Production. Ann. Rheum. Dis. 2018, 77, 1773-1781. [CrossRef] [PubMed]

23. Visciano, C.; Liotti, F.; Prevete, N.; Cali, G.; Franco, R.; Collina, F.; de Paulis, A.; Marone, G.; Santoro, M.; Melillo, R.M. Mast Cells Induce Epithelial-to-Mesenchymal Transition and Stem Cell Features in Human Thyroid Cancer Cells through an Il-8-Akt-Slug Pathway. Oncogene 2015, 34, 5175-5186. [CrossRef]

24. Galdiero, M.R.; Varricchi, G.; Marone, G. The Immune Network in Thyroid Cancer. Oncoimmunology 2016, 5, e1168556. [CrossRef] [PubMed]

25. Varricchi, G.; Galdiero, M.R.; Loffredo, S.; Marone, G.; Iannone, R.; Granata, F. Are Mast Cells Masters in Cancer? Front. Immunol. 2017, 8, 424. [CrossRef]

26. Varricchi, G.; Galdiero, M.R.; Marone, G.; Granata, F.; Borriello, F. Controversial Role of Mast Cells in Skin Cancers. Exp. Dermatol. 2017, 26, 11-17. [CrossRef]

27. Coleman, J.W.; Godfrey, R.C. The Number and Affinity of Ige Receptors on Dispersed Human Lung Mast Cells. Immunology 1981, $44,859-863$.

28. Guo, C.B.; Kagey-Sobotka, A.; Lichtenstein, L.M.; Bochner, B.S. Immunophenotyping and Functional Analysis of Purified Human Uterine Mast Cells. Blood 1992, 79, 708-712. [CrossRef]

29. Ravetch, J.V.; Kinet, J.P. Fc Receptors. Annu. Rev. Immunol. 1991, 9, 457-492. [CrossRef]

30. Blank, U.; Ra, C.S.; Kinet, J.P. Characterization of Truncated Alpha Chain Products from Human, Rat, and Mouse High Affinity Receptor for Immunoglobulin E. J. Biol. Chem. 1991, 266, 2639-2646. [CrossRef]

31. Kinet, J.P. The High-Affinity Ige Receptor (Fc Epsilon Ri): From Physiology to Pathology. Annu. Rev. Immunol. 1999, 17, 931-972. [CrossRef]

32. Dvorak, A.M.; Schulman, E.S.; Peters, S.P.; MacGlashan, D.W.; Newball, H.H., Jr.; Schleimer, R.P.; Lichtenstein, L.M. Immunoglobulin E-Mediated Degranulation of Isolated Human Lung Mast Cells. Lab Investig. 1985, 53, 45-56.

33. MacGlashan, D., Jr.; Lichtenstein, L.M. Basic Characteristics of Human Lung Mast Cell Desensitization. J. Immunol. 1987, 139, 501-505. [PubMed] 
34. Burke, S.M.; Issekutz, T.B.; Mohan, K.; Lee, P.W.; Shmulevitz, M.; Marshall, J.S. Human Mast Cell Activation with Virus-Associated Stimuli Leads to the Selective Chemotaxis of Natural Killer Cells by a Cxcl8-Dependent Mechanism. Blood 2008, 111, 5467-5476. [CrossRef]

35. Allakhverdi, Z.; Smith, D.E.; Comeau, M.R.; Delespesse, G. Cutting Edge: The St2 Ligand Il-33 Potently Activates and Drives Maturation of Human Mast Cells. J. Immunol. 2007, 179, 2051-2054.

36. Staiano, R.I.; Loffredo, S.; Borriello, F.; Iannotti, F.A.; Piscitelli, F.; Orlando, P.; Secondo, A.; Granata, F.; Lepore, M.T.; Fiorelli, A.; et al. Human Lung-Resident Macrophages Express Cb1 and Cb2 Receptors Whose Activation Inhibits the Release of Angiogenic and Lymphangiogenic Factors. J. Leukoc Biol. 2016, 99, 531-540. [CrossRef]

37. De Paulis, A.; Prevete, N.; Fiorentino, I.; Rossi, F.W.; Staibano, S.; Montuori, N.; Ragno, P.; Longobardi, A.; Liccardo, B.; Genovese, A.; et al. Expression and Functions of the Vascular Endothelial Growth Factors and Their Receptors in Human Basophils. J. Immunol. 2006, 177, 7322-7331.

38. Loffredo, S.; Borriello, F.; Iannone, R.; Ferrara, A.L.; Galdiero, M.R.; Gigantino, V.; Esposito, P.; Varricchi, G.; Lambeau, G.; Cassatella, M.A.; et al. Group V Secreted Phospholipase A2 Induces the Release of Proangiogenic and Antiangiogenic Factors by Human Neutrophils. Front. Immunol. 2017, 8, 443. [CrossRef]

39. Thomas, D.; Chou, S.; Dauwalder, O.; Lina, G. Diversity in Staphylococcus Aureus Enterotoxins. Chem. Immunol. Allergy 2007, 93, 24-41.

40. Abdurrahman, G.; Schmiedeke, F.; Bachert, C.; Broker, B.M.; Holtfreter, S. Allergy-a New Role for T Cell Superantigens of Staphylococcus Aureus? Toxins (Basel) 2020, 12, 176.

41. Becker, S.; Frankel, M.B.; Schneewind, O.; Missiakas, D. Release of Protein a from the Cell Wall of Staphylococcus Aureus. Proc. Natl. Acad. Sci. USA 2014, 111, 1574-1579. [CrossRef] [PubMed]

42. Forsgren, A.; Sjoquist, J. Protein a from S. Aureus. I. Pseudo-Immune Reaction with Human Gamma-Globulin. J. Immunol. 1966, 97, 822-827. [PubMed]

43. Inganas, M. Comparison of Mechanisms of Interaction between Protein a from Staphylococcus Aureus and Human Monoclonal Igg, Iga and Igm in Relation to the Classical Fc Gamma and the Alternative F( $\left.\mathrm{Ab}^{\prime}\right) 2$ Epsilon Protein a Interactions. Scand. J. Immunol. 1981, 13, 343-352. [CrossRef] [PubMed]

44. Goodyear, C.S.; Silverman, G.J. B Cell Superantigens: A Microbe's Answer to Innate-Like B Cells and Natural Antibodies. Springer Semin. Immunopathol. 2005, 26, 463-484. [CrossRef] [PubMed]

45. Bjorck, L.; Protein, L. A Novel Bacterial Cell Wall Protein with Affinity for Ig L Chains. J. Immunol. 1988, 140, 1194-1197. [PubMed]

46. Patella, V.; Casolaro, V.; Bjorck, L.; Marone, G.; Protein, L. A Bacterial Ig-Binding Protein That Activates Human Basophils and Mast Cells. J. Immunol. 1990, 145, 3054-3061.

47. Genovese, A.; Bouvet, J.P.; Florio, G.; Lamparter-Schummert, B.; Bjorck, L.; Marone, G. Bacterial Immunoglobulin Superantigen Proteins a and L Activate Human Heart Mast Cells by Interacting with Immunoglobulin E. Infect Immun. 2000, 68, 5517-5524. [CrossRef]

48. Genovese, A.; Borgia, G.; Bjorck, L.; Petraroli, A.; de Paulis, A.; Piazza, M.; Marone, G. Immunoglobulin Superantigen Protein L Induces Il-4 and Il-13 Secretion from Human Fc Epsilon Ri+ Cells through Interaction with the Kappa Light Chains of Ige. J. Immunol. 2003, 170, 1854-1861. [CrossRef]

49. Nilson, B.H.; Solomon, A.; Bjorck, L.; Akerstrom, B. Protein L from Peptostreptococcus Magnus Binds to the Kappa Light Chain Variable Domain. J. Biol. Chem. 1992, 267, 2234-2239. [CrossRef]

50. Marone, G.; Rossi, F.W.; Detoraki, A.; Granata, F.; Genovese, A.; Spadaro, G. Role of Superallergens in Allergic Disorders. Chem. Immunol. Allergy 2007, 93, 195-213.

51. Rha, M.S.; Kim, S.W.; Chang, D.Y.; Lee, J.K.; Kim, J.; Park, S.H.; Khalmuratova, R.; Lim, H.S.; Eun, K.M.; Hong, S.N.; et al. Superantigen-Related Th2 Cd4(+) T Cells in Nonasthmatic Chronic Rhinosinusitis with Nasal Polyps. J. Allergy Clin. Immunol. 2020, 145, 1378-1388. [CrossRef] [PubMed]

52. Teufelberger, A.R.; Broker, B.M.; Krysko, D.V.; Bachert, C.; Krysko, O. Staphylococcus Aureus Orchestrates Type 2 Airway Diseases. Trends Mol. Med. 2019, 25, 696-707. [CrossRef] [PubMed]

53. Tsilochristou, O.; Toit, G.d.; Sayre, P.H.; Roberts, G.; Lawson, K.; Sever, M.L.; Bahnson, H.T.; Radulovic, S.; Basting, M.; Plaut, M.; et al. Association of Staphylococcus Aureus Colonization with Food Allergy Occurs Independently of Eczema Severity. J. Allergy Clin. Immunol. 2019, 144, 494-503. [CrossRef] [PubMed]

54. Bachert, C.; Gevaert, P.; Zhang, N.; van Zele, T.; Perez-Novo, C. Role of Staphylococcal Superantigens in Airway Disease. Chem. Immunol. Allergy 2007, 93, 214-236. [PubMed]

55. Kim, Y.C.; Won, H.K.; Lee, J.W.; Sohn, K.H.; Kim, M.H.; Kim, T.B.; Chang, Y.S.; Lee, B.J.; Cho, S.H.; Bachert, C.; et al. Staphylococcus Aureus Nasal Colonization and Asthma in Adults: Systematic Review and Meta-Analysis. J. Allergy Clin. Immunol. Pract. 2019, 7 , 606-615. [CrossRef] [PubMed]

56. Li, J.; Yang, J.; Lu, Y.W.; Wu, S.; Wang, M.R.; Zhu, J.M. Possible Role of Staphylococcal Enterotoxin B in the Pathogenesis of Autoimmune Diseases. Viral Immunol. 2015, 28, 354-359. [CrossRef]

57. Viau, M.; Zouali, M. B-Lymphocytes, Innate Immunity, and Autoimmunity. Clin. Immunol. 2005, 114, 17-26. [CrossRef]

58. He, Y.; Sun, Y.; Ren, Y.; Qiao, L.; Guo, R.; Du, J.; Zhu, X.; Liu, Y.; Lin, J. The T Cell Activating Properties and Antitumour Activity of Staphylococcal Enterotoxin-Like Q. Med. Microbiol. Immunol. 2019, 208, 781-792. [CrossRef] 
59. Golob-Urbanc, A.; Rajcevic, U.; Strmsek, Z.; Jerala, R. Design of Split Superantigen Fusion Proteins for Cancer Immunotherapy. J. Biol. Chem. 2019, 294, 6294-6305. [CrossRef]

60. Agheli, R.; Emkanian, B.; Halabian, R.; Mehrabadi, J.F.; Fooladi, A.A.I. Recombinant Staphylococcal Enterotoxin Type a Stimulate Antitumoral Cytokines. Technol. Cancer Res. Treat 2017, 16, 125-132. [CrossRef]

61. Schmitz, J.; Owyang, A.; Oldham, E.; Song, Y.; Murphy, E.; McClanahan, T.K.; Zurawski, G.; Moshrefi, M.; Qin, J.; Li, X.; et al. Il-33, an Interleukin-1-Like Cytokine That Signals Via the Il-1 Receptor-Related Protein St2 and Induces T Helper Type 2-Associated Cytokines. Immunity 2005, 23, 479-490. [CrossRef] [PubMed]

62. Cayrol, C.; Girard, J.P. Interleukin-33 (Il-33): A Nuclear Cytokine from the Il-1 Family. Immunol. Rev. 2018, 281, 154-168. [CrossRef] [PubMed]

63. Boraschi, D.; Italiani, P.; Weil, S.; Martin, M.U. The Family of the Interleukin-1 Receptors. Immunol. Rev. 2018, 281, 197-232. [PubMed]

64. Martin, N.T.; Martin, M.U. Interleukin 33 Is a Guardian of Barriers and a Local Alarmin. Nat. Immunol. 2016, 17, 122-131. [PubMed]

65. Moussion, C.; Ortega, N.; Girard, J.P. The Il-1-Like Cytokine Il-33 Is Constitutively Expressed in the Nucleus of Endothelial Cells and Epithelial Cells in Vivo: A Novel 'Alarmin'? PLoS ONE 2008, 3, e3331. [CrossRef]

66. Afferni, C.; Buccione, C.; Andreone, S.; Galdiero, M.R.; Varricchi, G.; Marone, G.; Mattei, F.; Schiavoni, G. The Pleiotropic Immunomodulatory Functions of Il-33 and Its Implications in Tumor Immunity. Front. Immunol. 2018, 9, 2601. [CrossRef]

67. Drake, L.Y.; Kita, H. Il-33: Biological Properties, Functions, and Roles in Airway Disease. Immunol. Rev. 2017, $278,173-184$. [CrossRef]

68. Babina, M.; Wang, Z.; Franke, K.; Guhl, S.; Artuc, M.; Zuberbier, T. Yin-Yang of Il-33 in Human Skin Mast Cells: Reduced Degranulation, but Augmented Histamine Synthesis through P38 Activation. J. Investig. Dermatol. 2019, 139, $1516-1525$. [CrossRef]

69. Joulia, R.; L'Faqihi, F.E.; Valitutti, S.; Espinosa, E. Il-33 Fine Tunes Mast Cell Degranulation and Chemokine Production at the Single-Cell Level. J. Allergy Clin. Immunol. 2017, 140, 497-509. [CrossRef]

70. Morita, H.; Arae, K.; Unno, H.; Miyauchi, K.; Toyama, S.; Nambu, A.; Oboki, K.; Ohno, T.; Motomura, K.; Matsuda, A.; et al. An Interleukin-33-Mast Cell-Interleukin-2 Axis Suppresses Papain-Induced Allergic Inflammation by Promoting Regulatory T Cell Numbers. Immunity 2015, 43, 175-186. [CrossRef]

71. Taracanova, A.; Alevizos, M.; Karagkouni, A.; Weng, Z.; Norwitz, E.; Conti, P.; Leeman, S.E.; Theoharides, T.C. Sp and Il-33 Together Markedly Enhance Tnf Synthesis and Secretion from Human Mast Cells Mediated by the Interaction of Their Receptors. Proc. Natl. Acad. Sci. USA 2017, 114, E4002-E4009. [CrossRef] [PubMed]

72. Bandara, G.; Beaven, M.A.; Olivera, A.; Gilfillan, A.M.; Metcalfe, D.D. Activated Mast Cells Synthesize and Release Soluble St2-a Decoy Receptor for Il-33. Eur. J. Immunol. 2015, 45, 3034-3044. [CrossRef] [PubMed]

73. Salamon, P.; Shefler, I.; Moshkovits, I.; Munitz, A.; Klotzman, D.H.; Mekori, Y.A.; Hershko, A.Y. Il-33 and Ige Stimulate Mast Cell Production of Il-2 and Regulatory T Cell Expansion in Allergic Dermatitis. Clin. Exp. Allergy 2017, 47, 1409-1416. [CrossRef] [PubMed]

74. Wang, Z.; Guhl, S.; Franke, K.; Artuc, M.; Zuberbier, T.; Babina, M. Il-33 and Mrgprx2-Triggered Activation of Human Skin Mast Cells-Elimination of Receptor Expression on Chronic Exposure, but Reinforced Degranulation on Acute Priming. Cells 2019, 8, 341. [CrossRef]

75. Tjota, M.Y.; Williams, J.W.; Lu, T.; Clay, B.S.; Byrd, T.; Hrusch, C.L.; Decker, D.C.; de Araujo, C.A.; Bryce, P.J.; Sperling, A.I. Il-33-Dependent Induction of Allergic Lung Inflammation by Fcgammariii Signaling. J. Clin. Investig. 2013, 123, 2287-2297. [CrossRef]

76. Loxham, M.; Davies, D.E. Phenotypic and Genetic Aspects of Epithelial Barrier Function in Asthmatic Patients. J. Allergy Clin. Immunol. 2017, 139, 1736-1751. [CrossRef]

77. Cayrol, C.; Duval, A.; Schmitt, P.; Roga, S.; Camus, M.; Stella, A.; Burlet-Schiltz, O.; Gonzalez-de-Peredo, A.; Girard, J.P. Environmental Allergens Induce Allergic Inflammation through Proteolytic Maturation of Il-33. Nat. Immunol. 2018, 19, 375-385. [CrossRef]

78. Altman, M.C.; Lai, Y.; Nolin, J.D.; Long, S.; Chen, C.C.; Piliponsky, A.M.; Altemeier, W.A.; Larmore, M.; Frevert, C.W.; Mulligan, M.S.; et al. Airway Epithelium-Shifted Mast Cell Infiltration Regulates Asthmatic Inflammation Via Il-33 Signaling. J. Clin. Investig. 2019, 129, 4979-4991. [CrossRef]

79. Werder, R.B.; Zhang, V.; Lynch, J.P.; Snape, N.; Upham, J.W.; Spann, K.; Phipps, S. Chronic Il-33 Expression Predisposes to Virus-Induced Asthma Exacerbations by Increasing Type 2 Inflammation and Dampening Antiviral Immunity. J. Allergy Clin. Immunol. 2018, 141, 1607-1619. [CrossRef]

80. Alves-Filho, J.C.; Sonego, F.; Souto, F.O.; Freitas, A.; Verri, W.A.; Auxiliadora-Martins, M., Jr.; Basile-Filho, A.; McKenzie, A.N.; $\mathrm{Xu}$, D.; Cunha, F.Q.; et al. Interleukin-33 Attenuates Sepsis by Enhancing Neutrophil Influx to the Site of Infection. Nat. Med. 2010, 16, 708-712. [CrossRef]

81. Kearley, J.; Silver, J.S.; Sanden, C.; Liu, Z.; Berlin, A.A.; White, N.; Mori, M.; Pham, T.H.; Ward, C.K.; Criner, G.J.; et al. Cigarette Smoke Silences Innate Lymphoid Cell Function and Facilitates an Exacerbated Type I Interleukin-33-Dependent Response to Infection. Immunity 2015, 42, 566-579. [CrossRef] [PubMed] 
82. Zizzo, G.; Cohen, P.L. Imperfect Storm: Is Interleukin-33 the Achilles Heel of Covid-19? Lancet Rheumatol. 2020, 2, e779-e790. [CrossRef]

83. Liew, F.Y.; Girard, J.P.; Turnquist, H.R. Interleukin-33 in Health and Disease. Nat. Rev. Immunol. 2016, 16, 676-689. [CrossRef] [PubMed]

84. Hollande, C.; Boussier, J.; Ziai, J.; Nozawa, T.; Bondet, V.; Phung, W.; Lu, B.; Duffy, D.; Paradis, V.; Mallet, V.; et al. Inhibition of the Dipeptidyl Peptidase Dpp4 (Cd26) Reveals Il-33-Dependent Eosinophil-Mediated Control of Tumor Growth. Nat. Immunol. 2019, 20, 257-264. [CrossRef]

85. Marone, G.; Casolaro, V.; Paganelli, R.; Quinti, I. Igg Anti-Ige from Atopic Dermatitis Induces Mediator Release from Basophils and Mast Cells. J. Investig. Dermatol. 1989, 93, 246-252. [CrossRef] [PubMed]

86. Marone, G.; Spadaro, G.; Palumbo, C.; Condorelli, G. The Anti-Ige/Anti-Fcepsilonrialpha Autoantibody Network in Allergic and Autoimmune Diseases. Clin. Exp. Allergy 1999, 29, 17-27. [CrossRef]

87. Patella, V.; Marino, I.; Arbustini, E.; Lamparter-Schummert, B.; Verga, L.; Adt, M.; Marone, G. Stem Cell Factor in Mast Cells and Increased Mast Cell Density in Idiopathic and Ischemic Cardiomyopathy. Circulation 1998, 97, 971-978. [CrossRef]

88. Patella, V.; Giuliano, A.; Bouvet, J.P.; Marone, G. Endogenous Superallergen Protein Fv Induces Il-4 Secretion from Human Fc Epsilon Ri+Cells through Interaction with the Vh3 Region of Ige. J. Immunol. 1998, 161, 5647-5655.

89. Marone, G.; Tamburini, M.; Giudizi, M.G.; Biagiotti, R.; Almerigogna, F.; Romagnani, S. Mechanism of Activation of Human Basophils by Staphylococcus Aureus Cowan 1. Infect Immun. 1987, 55, 803-809. [CrossRef]

90. Sala, P.; Tonutti, E.; Ruscio, M.; Colle, R.; Antonutto, G.; Falconieri, G. Ige Myeloma. Report of a New Case and Review of the Literature. Haematologica 1981, 66, 787-795.

91. Patella, V.; de Crescenzo, G.; Marino, I.; Genovese, A.; Adt, M.; Gleich, G.J.; Marone, G. Eosinophil Granule Proteins Activate Human Heart Mast Cells. J. Immunol. 1996, 157, 1219-1225. [PubMed]

92. Siraganian, R.P. An Automated Continuous-Flow System for the Extraction and Fluorometric Analysis of Histamine. Anal. Biochem. 1974, 57, 383-394. [CrossRef]

93. Loffredo, S.; Ferrara, A.L.; Bova, M.; Borriello, F.; Suffritti, C.; Veszeli, N.; Petraroli, A.; Galdiero, M.R.; Varricchi, G.; Granata, F.; et al. Secreted Phospholipases A2 in Hereditary Angioedema with C1-Inhibitor Deficiency. Front. Immunol. $2018,9,1721$. [CrossRef] [PubMed]

94. Marone, G.; Rossi, F.W.; Pecoraro, A.; Pucino, V.; Criscuolo, G.; Paulis, A.; Spadaro, G.; Varricchi, G. Hiv Gp120 Induces the Release of Proinflammatory, Angiogenic, and Lymphangiogenic Factors from Human Lung Mast Cells. Vaccines (Basel) 2020, 8 , 208. [CrossRef] [PubMed]

95. Stentzel, S.; Teufelberger, A.; Nordengrun, M.; Kolata, J.; Schmidt, F.; van Crombruggen, K.; Michalik, S.; Kumpfmuller, J.; Tischer, S.; Schweder, T.; et al. Staphylococcal Serine Protease-Like Proteins Are Pacemakers of Allergic Airway Reactions to Staphylococcus Aureus. J. Allergy Clin. Immunol. 2017, 139, 492-500. [CrossRef]

96. Huvenne, W.; Callebaut, I.; Plantinga, M.; Vanoirbeek, J.A.; Krysko, O.; Bullens, D.M.; Gevaert, P.; van Cauwenberge, P.; Lambrecht, B.N.; Ceuppens, J.L.; et al. Staphylococcus Aureus Enterotoxin B Facilitates Allergic Sensitization in Experimental Asthma. Clin. Exp. Allergy 2010, 40, 1079-1090. [CrossRef]

97. Rocha-de-Souza, C.M.; Berent-Maoz, B.; Mankuta, D.; Moses, A.E.; Levi-Schaffer, F. Human Mast Cell Activation by Staphylococcus Aureus: Interleukin- 8 and Tumor Necrosis Factor Alpha Release and the Role of Toll-Like Receptor 2 and Cd48 Molecules. Infect. Immun. 2008, 76, 4489-4497. [CrossRef]

98. Varricchi, G.; Loffredo, S.; Borriello, F.; Pecoraro, A.; Rivellese, F.; Genovese, A.; Spadaro, G.; Marone, G. Superantigenic Activation of Human Cardiac Mast Cells. Int. J. Mol. Sci. 2019, 20, 1828. [CrossRef]

99. Kaur, D.; Gomez, E.; Doe, C.; Berair, R.; Woodman, L.; Saunders, R.; Hollins, F.; Rose, F.R.; Amrani, Y.; May, R.; et al. Il-33 Drives Airway Hyper-Responsiveness through Il-13-Mediated Mast Cell: Airway Smooth Muscle Crosstalk. Allergy 2015, 70, 556-567. [CrossRef]

100. Ho, L.H.; Ohno, T.; Oboki, K.; Kajiwara, N.; Suto, H.; Iikura, M.; Okayama, Y.; Akira, S.; Saito, H.; Galli, S.J.; et al. Il-33 Induces Il-13 Production by Mouse Mast Cells Independently of Ige-Fcepsilonri Signals. J. Leukoc Biol. 2007, 82, 1481-1490. [CrossRef]

101. Kashiwakura, J.; Yanagisawa, M.; Lee, H.; Okamura, Y.; Sasaki-Sakamoto, T.; Saito, S.; Tokuhashi, Y.; Ra, C.; Okayama, Y. Interleukin-33 Synergistically Enhances Immune Complex-Induced Tumor Necrosis Factor Alpha and Interleukin-8 Production in Cultured Human Synovium-Derived Mast Cells. Int. Arch. Allergy Immunol. 2013, 161 (Suppl. 2), 32-36. [CrossRef] [PubMed]

102. Myhre, E.B.; Erntell, M. A Non-Immune Interaction between the Light Chain of Human Immunoglobulin and a Surface Component of a Peptococcus Magnus Strain. Mol. Immunol. 1985, 22, 879-885. [CrossRef]

103. Lambrecht, B.N.; Hammad, H.; Fahy, J.V. The Cytokines of Asthma. Immunity 2019, 50, 975-991. [CrossRef] [PubMed]

104. Peters, M.C.; Wenzel, S.E. Intersection of Biology and Therapeutics: Type 2 Targeted Therapeutics for Adult Asthma. Lancet 2020, 395, 371-383. [CrossRef]

105. Maun, H.R.; Jackman, J.K.; Choy, D.F.; Loyet, K.M.; Staton, T.L.; Jia, G.; Dressen, A.; Hackney, J.A.; Bremer, M.; Walters, B.T.; et al. An Allosteric Anti-Tryptase Antibody for the Treatment of Mast Cell-Mediated Severe Asthma. Cell 2019, 179, 417-431. [CrossRef]

106. Bigna, J.J.; Kenne, A.M.; Asangbeh, S.L.; Sibetcheu, A.T. Prevalence of Chronic Obstructive Pulmonary Disease in the Global Population with Hiv: A Systematic Review and Meta-Analysis. Lancet Glob. Health 2018, 6, e193-e202. [CrossRef]

107. Elieh Ali Komi, D.; Bjermer, L. Mast Cell-Mediated Orchestration of the Immune Responses in Human Allergic Asthma: Current Insights. Clin. Rev. Allergy Immunol. 2019, 56, 234-247. [CrossRef] 
108. Salamon, P.; Mekori, Y.A.; Shefler, I. Lung Cancer-Derived Extracellular Vesicles: A Possible Mediator of Mast Cell Activation in the Tumor Microenvironment. Cancer Immunol. Immunother. 2020, 69, 373-381. [CrossRef]

109. McDowell, P.J.; Heaney, L.G. Different Endotypes and Phenotypes Drive the Heterogeneity in Severe Asthma. Allergy 2020, 75, 302-310. [CrossRef]

110. Sze, E.; Bhalla, A.; Nair, P. Mechanisms and Therapeutic Strategies for Non-T2 Asthma. Allergy 2020, 75, 311-325. [CrossRef]

111. Samitas, K.; Zervas, E.; Gaga, M. T2-Low Asthma: Current Approach to Diagnosis and Therapy. Curr. Opin. Pulm. Med. 2017, 23, 48-55. [CrossRef]

112. Davis, M.F.; Peng, R.D.; McCormack, M.C.; Matsui, E.C. Staphylococcus Aureus Colonization Is Associated with Wheeze and Asthma among Us Children and Young Adults. J. Allergy Clin. Immunol. 2015, 135, 811-813. [CrossRef]

113. Bachert, C.; van Steen, K.; Zhang, N.; Holtappels, G.; Cattaert, T.; Maus, B.; Buhl, R.; Taube, C.; Korn, S.; Kowalski, M.; et al. Specific Ige against Staphylococcus Aureus Enterotoxins: An Independent Risk Factor for Asthma. J. Allergy Clin. Immunol. 2012, 130, 376-381. [CrossRef]

114. Alitalo, K. The Lymphatic Vasculature in Disease. Nat. Med. 2011, 17, 1371-1380. [CrossRef]

115. Brakenhielm, E.; Alitalo, K. Cardiac Lymphatics in Health and Disease. Nat. Rev. Cardiol. 2019, 16, 56-68. [CrossRef]

116. Bachert, C.; Zhang, N.; Holtappels, G.; de Lobel, L.; van Cauwenberge, P.; Liu, S.; Lin, P.; Bousquet, J.; van Steen, K. Presence of Il-5 Protein and Ige Antibodies to Staphylococcal Enterotoxins in Nasal Polyps Is Associated with Comorbid Asthma. J. Allergy Clin. Immunol. 2010, 126, 962-968.e6. [CrossRef]

117. Aman, M.J. Superantigens of a Superbug: Major Culprits of Staphylococcus Aureus Disease? Virulence 2017, 8, 607-610. [CrossRef]

118. Teufelberger, A.R.; Nordengrun, M.; Braun, H.; Maes, T.; de Grove, K.; Holtappels, G.; O’Brien, C.; Provoost, S.; Hammad, H.; Goncalves, A.; et al. The Il-33/St2 Axis Is Crucial in Type 2 Airway Responses Induced by Staphylococcus Aureus-Derived Serine Protease-Like Protein D. J. Allergy Clin. Immunol. 2018, 141, 549-559. [CrossRef]

119. Bachert, C.; Claeys, S.E.; Tomassen, P.; van Zele, T.; Zhang, N. Rhinosinusitis and Asthma: A Link for Asthma Severity. Curr. Allergy Asthma Rep. 2010, 10, 194-201. [CrossRef]

120. Tomassen, P.; Vandeplas, G.; van Zele, T.; Cardell, L.O.; Arebro, J.; Olze, H.; Forster-Ruhrmann, U.; Kowalski, M.L.; OlszewskaZiaber, A.; Holtappels, G.; et al. Inflammatory Endotypes of Chronic Rhinosinusitis Based on Cluster Analysis of Biomarkers. J. Allergy Clin. Immunol. 2016, 137, 1449-1456. [CrossRef]

121. Vigorito, C.; Giordano, A.; Cirillo, R.; Genovese, A.; Rengo, F.; Marone, G. Metabolic and Hemodynamic Effects of Peptide Leukotriene C4 and D4 in Man. Int. J. Clin. Lab. Res. 1997, 27, 178-184. [CrossRef] [PubMed]

122. Varricchi, G.; Galdiero, M.R.; Tocchetti, C.G. Cardiac Toxicity of Immune Checkpoint Inhibitors: Cardio-Oncology Meets Immunology. Circulation 2017, 136, 1989-1992. [CrossRef] [PubMed]

123. Varricchi, G.; Marone, G.; Kovanen, P.T. Cardiac Mast Cells: Underappreciated Immune Cells in Cardiovascular Homeostasis and Disease. Trends Immunol. 2020, 41, 734-746. [CrossRef] [PubMed]

124. Lai, J.F.; Thompson, L.J.; Ziegler, S.F. Tslp Drives Acute Th2-Cell Differentiation in Lungs. J. Allergy Clin. Immunol. 2020, $146,1406$. [CrossRef] [PubMed]

125. Marone, G.; Spadaro, G.; Braile, M.; Poto, R.; Criscuolo, G.; Pahima, H.; Loffredo, S.; Levi-Schaffer, F.; Varricchi, G. Tezepelumab: A Novel Biological Therapy for the Treatment of Severe Uncontrolled Asthma. Expert Opin. Investig. Drugs 2019, 28, 931-940. [CrossRef] [PubMed]

126. Varricchi, G.; Pecoraro, A.; Marone, G.; Criscuolo, G.; Spadaro, G.; Genovese, A. Thymic Stromal Lymphopoietin Isoforms, Inflammatory Disorders, and Cancer. Front. Immunol. 2018, 9, 1595. [CrossRef]

127. Chu, D.K.; Llop-Guevara, A.; Walker, T.D.; Flader, K.; Goncharova, S.; Boudreau, J.E.; Moore, C.L.; In, T.S.; Waserman, S.; Coyle, A.J.; et al. Il-33, but Not Thymic Stromal Lymphopoietin or Il-25, Is Central to Mite and Peanut Allergic Sensitization. J. Allergy Clin. Immunol. 2013, 131, 187-200.e1-8. [CrossRef]

128. Iijima, K.; Kobayashi, T.; Hara, K.; Kephart, G.M.; Ziegler, S.F.; McKenzie, A.N.; Kita, H. Il-33 and Thymic Stromal Lymphopoietin Mediate Immune Pathology in Response to Chronic Airborne Allergen Exposure. J. Immunol. 2014, 193, 1549-1559. [CrossRef]

129. Prefontaine, D.; Nadigel, J.; Chouiali, F.; Audusseau, S.; Semlali, A.; Chakir, J.; Martin, J.G.; Hamid, Q. Increased Il-33 Expression by Epithelial Cells in Bronchial Asthma. J. Allergy Clin. Immunol. 2010, 125, 752-754. [CrossRef]

130. Beale, J.; Jayaraman, A.; Jackson, D.J.; Macintyre, J.D.R.; Edwards, M.R.; Walton, R.P.; Zhu, J.; Ching, Y.M.; Shamji, B.; Edwards, M.; et al. Rhinovirus-Induced Il-25 in Asthma Exacerbation Drives Type 2 Immunity and Allergic Pulmonary Inflammation. Sci. Transl. Med. 2014, 6, 256ra134. [CrossRef]

131. Lambrecht, B.N.; Hammad, H. The Immunology of Asthma. Nat. Immunol. 2015, 16, 45-56. [CrossRef] [PubMed]

132. Ying, S.; O'Connor, B.; Ratoff, J.; Meng, Q.; Mallett, K.; Cousins, D.; Robinson, D.; Zhang, G.; Zhao, J.; Lee, T.H.; et al. Thymic Stromal Lymphopoietin Expression Is Increased in Asthmatic Airways and Correlates with Expression of Th2-Attracting Chemokines and Disease Severity. J. Immunol. 2005, 174, 8183-8190. [CrossRef] [PubMed]

133. Enoksson, M.; Lyberg, K.; Moller-Westerberg, C.; Fallon, P.G.; Nilsson, G.; Lunderius-Andersson, C. Mast Cells as Sensors of Cell Injury through Il-33 Recognition. J. Immunol. 2011, 186, 2523-2528. [CrossRef] [PubMed]

134. Tatari, N.; Movassagh, H.; Shan, L.; Koussih, L.; Gounni, A.S. Semaphorin 3e Inhibits House Dust Mite-Induced Angiogenesis in a Mouse Model of Allergic Asthma. Am. J. Pathol. 2019, 189, 762-772. [CrossRef] 
135. Chatterjee, S.; Heukamp, L.C.; Siobal, M.; Schottle, J.; Wieczorek, C.; Peifer, M.; Frasca, D.; Koker, M.; Konig, K.; Meder, L.; et al. Tumor Vegf:Vegfr2 Autocrine Feed-Forward Loop Triggers Angiogenesis in Lung Cancer. J. Clin. Investig. 2013, 123, $1732-1740$. [CrossRef]

136. Bosisio, D.; Ronca, R.; Salvi, V.; Presta, M.; Sozzani, S. Dendritic Cells in Inflammatory Angiogenesis and Lymphangiogenesis. Curr. Opin. Immunol. 2018, 53, 180-186. [CrossRef]

137. Wilson, A.M.; Shao, Z.; Grenier, V.; Mawambo, G.; Daudelin, J.F.; Dejda, A.; Pilon, F.; Popovic, N.; Boulet, S.; Parinot, C.; et al. Neuropilin-1 Expression in Adipose Tissue Macrophages Protects against Obesity and Metabolic Syndrome. Sci. Immunol. 2018, 3, eaan4626. [CrossRef]

138. Stump, B.; Cui, Y.; Kidambi, P.; Lamattina, A.M.; El-Chemaly, S. Lymphatic Changes in Respiratory Diseases: More Than Just Remodeling of the Lung? Am. J. Respir. Cell Mol. Biol. 2017, 57, 272-279. [CrossRef]

139. Yao, L.C.; Baluk, P.; Feng, J.; McDonald, D.M. Steroid-Resistant Lymphatic Remodeling in Chronically Inflamed Mouse Airways. Am. J. Pathol. 2010, 176, 1525-1541. [CrossRef]

140. Hardavella, G.; Tzortzaki, E.G.; Siozopoulou, V.; Galanis, P.; Vlachaki, E.; Avgousti, M.; Stefanou, D.; Siafakas, N.M. Lymphangiogenesis in Copd: Another Link in the Pathogenesis of the Disease. Respir. Med. 2012, 106, 687-693. [CrossRef]

141. Mori, M.; Andersson, C.K.; Graham, G.J.; Lofdahl, C.G.; Erjefalt, J.S. Increased Number and Altered Phenotype of Lymphatic Vessels in Peripheral Lung Compartments of Patients with Copd. Respir. Res. 2013, 14, 65. [CrossRef]

142. Aspelund, A.; Robciuc, M.R.; Karaman, S.; Makinen, T.; Alitalo, K. Lymphatic System in Cardiovascular Medicine. Circ. Res. 2016, 118, 515-530. [CrossRef] [PubMed]

143. Varricchi, G.; de Paulis, A.; Marone, G.; Galli, S.J. Future Needs in Mast Cell Biology. Int. J. Mol. Sci. 2019, 20, 4397. [CrossRef] [PubMed]

144. Zheng, W.; Aspelund, A.; Alitalo, K. Lymphangiogenic Factors, Mechanisms, and Applications. J. Clin. Investig. 2014, 124, 878-887. [CrossRef] [PubMed]

145. Kim, H.; Kataru, R.P.; Koh, G.Y. Inflammation-Associated Lymphangiogenesis: A Double-Edged Sword? J. Clin. Investig. 2014, 124, 936-942. [CrossRef] [PubMed]

146. Pal, S.; Nath, S.; Meininger, C.J.; Gashev, A.A. Emerging Roles of Mast Cells in the Regulation of Lymphatic Immuno-Physiology. Front. Immunol. 2020, 11, 1234. [CrossRef]

147. Sammarco, G.; Varricchi, G.; Ferraro, V.; Ammendola, M.; de Fazio, M.; Altomare, D.F.; Luposella, M.; Maltese, L.; Curro, G.; Marone, G.; et al. Mast Cells, Angiogenesis and Lymphangiogenesis in Human Gastric Cancer. Int. J. Mol. Sci. 2019, $20,2106$. [CrossRef]

148. Fankhauser, M.; Broggi, M.A.S.; Potin, L.; Bordry, N.; Jeanbart, L.; Lund, A.W.; da Costa, E.; Hauert, S.; Rincon-Restrepo, M.; Tremblay, C.; et al. Tumor Lymphangiogenesis Promotes T Cell Infiltration and Potentiates Immunotherapy in Melanoma. Sci. Transl. Med. 2017, 9, eaal4712. [CrossRef]

149. Henri, O.; Pouehe, C.; Houssari, M.; Galas, L.; Nicol, L.; Edwards-Levy, F.; Henry, J.P.; Dumesnil, A.; Boukhalfa, I.; Banquet, S.; et al Selective Stimulation of Cardiac Lymphangiogenesis Reduces Myocardial Edema and Fibrosis Leading to Improved Cardiac Function Following Myocardial Infarction. Circulation 2016, 133, 1484-1497. [CrossRef]

150. Klotz, L.; Norman, S.; Vieira, J.M.; Masters, M.; Rohling, M.; Dube, K.N.; Bollini, S.; Matsuzaki, F.; Carr, C.A.; Riley, P.R. Cardiac Lymphatics Are Heterogeneous in Origin and Respond to Injury. Nature 2015, 522, 62-67. [CrossRef]

151. Huang, L.H.; Lavine, K.J.; Randolph, G.J. Cardiac Lymphatic Vessels, Transport, and Healing of the Infarcted Heart. JACC Basic Transl. Sci. 2017, 2, 477-483. [CrossRef]

152. Vieira, J.M.; Norman, S.; del Campo, C.V.; Cahill, T.J.; Barnette, D.N.; Gunadasa-Rohling, M.; Johnson, L.A.; Greaves, D.R.; Carr, C.A.; Jackson, D.G.; et al. The Cardiac Lymphatic System Stimulates Resolution of Inflammation Following Myocardial Infarction. J. Clin. Investig. 2018, 128, 3402-3412. [CrossRef] [PubMed]

153. Hallstrand, T.S.; Hackett, T.L.; Altemeier, W.A.; Matute-Bello, G.; Hansbro, P.M.; Knight, D.A. Airway Epithelial Regulation of Pulmonary Immune Homeostasis and Inflammation. Clin. Immunol. 2014, 151, 1-15. [CrossRef]

154. Kuchuk, O.; Tuccitto, A.; Citterio, D.; Huber, V.; Camisaschi, C.; Milione, M.; Vergani, B.; Villa, A.; Alison, M.R.; Carradori, S.; et al. $\mathrm{Ph}$ Regulators to Target the Tumor Immune Microenvironment in Human Hepatocellular Carcinoma. Oncoimmunology 2018, 7, e1445452. [CrossRef] [PubMed]

155. Gulliksson, M.; Carvalho, R.F.; Ulleras, E.; Nilsson, G. Mast Cell Survival and Mediator Secretion in Response to Hypoxia. PLoS ONE 2010, 5, e12360. [CrossRef] [PubMed]

156. Ramirez-Moreno, I.G.; Ibarra-Sanchez, A.; Castillo-Arellano, J.I.; Blank, U.; Gonzalez-Espinosa, C. Mast Cells Localize in Hypoxic Zones of Tumors and Secrete Ccl-2 under Hypoxia through Activation of L-Type Calcium Channels. J. Immunol. 2020, 204, 1056-1068. [CrossRef]

157. Abebayehu, D.; Spence, A.J.; Qayum, A.A.; Taruselli, M.T.; McLeod, J.J.; Caslin, H.L.; Chumanevich, A.P.; Kolawole, E.M.; Paranjape, A.; Baker, B.; et al. Lactic Acid Suppresses Il-33-Mediated Mast Cell Inflammatory Responses Via Hypoxia-Inducible Factor-1alpha-Dependent Mir-155 Suppression. J. Immunol. 2016, 197, 2909-2917. [CrossRef] [PubMed]

158. Gorzalczany, Y.; Akiva, E.; Klein, O.; Merimsky, O.; Sagi-Eisenberg, R. Mast Cells Are Directly Activated by Contact with Cancer Cells by a Mechanism Involving Autocrine Formation of Adenosine and Autocrine/Paracrine Signaling of the Adenosine A3 Receptor. Cancer Lett. 2017, 397, 23-32. [CrossRef]

159. Cekic, C.; Linden, J. Purinergic Regulation of the Immune System. Nat. Rev. Immunol. 2016, 16, 177-192. [CrossRef] [PubMed] 